Article

\title{
Impacts of Long- and Short-Term of Irrigation with Treated Wastewater and Synthetic Fertilizers on the Growth, Biomass, Heavy Metal Content, and Energy Traits of Three Potential Bioenergy Crops in Arid Regions
}

\author{
Mahmoud F. Seleiman ${ }^{1,2, *(\mathbb{D})}$, Nasser Al-Suhaibani ${ }^{1}$, Salah El-Hendawy ${ }^{1,3}{ }^{\mathbb{D}}$, Kamel Abdella ${ }^{1}$, Majed Alotaibi ${ }^{1}$ \\ and Ali Alderfasi ${ }^{1}$ \\ 1 Plant Production Department, College of Food and Agriculture Sciences, King Saud University, P.O. Box 2460, \\ Riyadh 11451, Saudi Arabia; nsuhaib@KSU.EDU.SA (N.A.-S.); mosalah@ksu.edu.sa (S.E.-H.); \\ kkamel58@yahoo.com (K.A.); malotaibia@KSU.EDU.SA (M.A.); aderfasi@gmail.com (A.A.) \\ 2 Department of Crop Sciences, Faculty of Agriculture, Menoufia University, Shibin El-kom 32514, Egypt \\ 3 Agronomy Department, Faculty of Agriculture, Suez Canal University, Ismailia 41522, Egypt \\ * Correspondence: mseleiman@ksu.edu.sa or mahmoud.seleiman@agr.menofia.edu.eg; Tel.: +966-553153351
}

Citation: Seleiman, M.F.; Al-Suhaibani, N.; El-Hendawy, S.; Abdella, K.; Alotaibi, M.; Alderfasi, A. Impacts of Long- and Short-Term of Irrigation with Treated Wastewater and Synthetic Fertilizers on the Growth, Biomass, Heavy Metal Content, and Energy Traits of Three Potential Bioenergy Crops in Arid Regions. Energies 2021, 14, 3037. https://doi.org/10.3390/en14113037

Academic Editor: Giovanni Esposito

Received: 28 March 2021

Accepted: 21 May 2021

Published: 24 May 2021

Publisher's Note: MDPI stays neutral with regard to jurisdictional claims in published maps and institutional affiliations.

Copyright: (c) 2021 by the authors. Licensee MDPI, Basel, Switzerland. This article is an open access article distributed under the terms and conditions of the Creative Commons Attribution (CC BY) license (https:// creativecommons.org/licenses/by/ $4.0 /)$.

Abstract: The availability of suitable water is an important factor for increasing the cultivated areas and sustainability in arid (i.e., less than $200 \mathrm{~mm}$ precipitation per year) and semiarid regions (i.e., 200-700 $\mathrm{mm}$ precipitation per year). Therefore, this study aimed to analyze the impact of treated wastewater (TWW) and groundwater (GW) as well as synthetic fertilizers $(50 \%$ and $100 \%$ of the recommended NPK dose; $150-150-60 \mathrm{~kg} \mathrm{~N}-\mathrm{P}_{2} \mathrm{O}_{5}-\mathrm{K}_{2} \mathrm{O}$ ha ${ }^{-1}$ ) on the growth, biomass, energy traits, and macro and trace elements of maize (Zea mays L.), sorghum (Sorghum bicolor L.), and pearl millet (Pennisetum glaucum L) grown in old cultivated (first location; L1) and virgin soil (L2 and L3) as potential bioenergy crops. The soil in L1 has been irrigated with treated wastewater for the last 15 years and continued to be irrigated with treated wastewater in this investigation. The virgin soil was divided into two parts: the first part was irrigated with TWW, and the second part was irrigated with GW. The experiments were laid out in a split-plot with a randomized complete block design with water treatments (TWW in old and virgin soil, and GW in virgin soil) in main plots, and the two treatments of fertilization (50\% and $100 \%$ of the recommended NPK dose) were distributed randomly in subplots. Compared with the crops irrigated with GW, the crops irrigated with TWW, whether grown on old or virgin soil, showed higher plant height, total chlorophyll content, leaf area per plant, total biomass, energy content, and gross energy with low ash. They also contained higher (but lower than permissible limits) concentrations of macro-elements (NPK) and trace elements ( $\mathrm{Fe}, \mathrm{Mn}, \mathrm{Cu}, \mathrm{Zn}$, $\mathrm{Cd}, \mathrm{Pb}, \mathrm{Ni}$, and $\mathrm{Co}$ ). In addition, the application of a 50\% recommended dose of NPK with TWW showed equivalent results to a $100 \%$ recommended dose of NPK on all measured parameters with few exceptions. In conclusion, the TWW can be used to irrigate field crops allocated for bioenergy production in arid regions because it does not harm the plants and environment. In addition, the $50 \%$ recommended dose of NPK fertilizer exerted no negative effects on the growth and energy production of field crops, thereby protecting the environment and reducing the leaching of excessive fertilizers into GW.

Keywords: bioenergy crops; wastewater; synthetic fertilizer; biomass; heavy metals

\section{Introduction}

Energy is a prerequisite for development in every society of the world, and it plays an important role in ecosystems and human civilization [1,2]. However, the conventional energy sources are not renewable, and their high utilization could result in a severe energy crisis [3]. In addition, excessive utilization of fossil fuels pollutes the environment, causing severe health hazards and accelerating global warming [4]. Therefore, bioenergy as a 
powerful renewable substitution to fossil fuels is emerging rapidly worldwide, particularly in developed countries, to meet the energy requirement of the world population and to mitigate global warming [2,4]. Furthermore, sustainable bioenergy production can effectively decrease the risks of energy crisis and help the economic growth of countries $[5,6]$. The exploitation of energy crops or agricultural crops are mainly grown for energy production, could reduce the world's dependence on fossil fuels and can decrease the release of greenhouse gases [2,4,7]. Energy crops are either native species or cultivated, new or traditional, which yield the biomass as the main output that can be utilized for different energy purposes, such as combustion or raw material for pyrolysis and gasification, and fermentation for ethanol production $[4,6,8]$. Thus, the concept of bioenergy crops is gaining significant consideration in the scientific community because of its renewability and environmental-friendly nature [3,4].

Maize (Zea mays L.), sorghum [Sorghum bicolor (L.) Moench], and pearl millet (Pennisetum glaucum L.) are important energy crops $[4,9,10]$ with high biomass production and diverse possible bioenergy uses [4,9]. They are $\mathrm{C} 4$ crops with exceptional daily dry matter accumulation and high nitrogen use efficiency [11]. Maize is an important feedstock crop because of its high biomass $32-54 \mathrm{t} \mathrm{ha}^{-1}[4,12,13]$ and superior starch accumulation [14]. Given its high percentage of volatile compounds and simple conversion, maize is a suitable crop for bioconversion [6]. In addition, maize is usually used for the starchy raw material and bioethanol present in grains and biomass, respectively. Biomass can be used for combustion or production of second-generation bioethanol [3,6]. Biomass or bioenergy sorghum is potentially an ideal feedstock for the cellulosic ethanol industry because it produces high yields and has suitable chemical properties for fuel conversion [15]. It is an important crop in warm areas and achieves higher yields with fewer inputs than many other bioenergy crops in arid and semiarid environments [16-18]. The aerial biomass yield of sorghum is high, ranging from $35 \mathrm{t} \mathrm{ha}^{-1}$ to $54 \mathrm{t} \mathrm{ha}^{-1}$ [19-21]. Pearl millet is utilized worldwide as a grain crop, a forage crop, or a high-biomass feedstock [22,23]. It has high levels of tolerance to drought, salinity, and temperature adaptation and can successfully be grown on poor and degraded lands [24,25]. It requires very low rainfall (less than $300 \mathrm{~mm}$ ) and less nitrogen amount than most other cereal crops [26], which qualifies it as an important crop for biomass production. Some genotypes of pearl millet can yield high dry matter, ranging from $15 \mathrm{t} \mathrm{ha}^{-1}$ to $25 \mathrm{t} \mathrm{ha}^{-1}$ [27]. Study on ethanol production from pearl millet has not received sufficient attention up until now, but the presence of high biomass coupled with its ethanol-friendly properties ensures a high possibility of this crop becoming the future bio-fuel crop of the marginal lands in semi-arid areas.

World Water Development Report 2014 showed a strong link between energy and water. Energy and water are interdependent, and any action taken in one sector can significantly influence the other sector positively or negatively [28]. Energy demand is progressively increasing in the world because of the fast-growing population. The rapidly growing population has also enhanced the rate of wastewater in recent decades. The application of untreated wastewater is however not suggested because it possesses different organic and inorganic chemicals, biodegradable materials, toxic substances, and disease-causing agents [29]. Wastewater is contaminated with heavy metals and trace elements, such as lead $(\mathrm{Pb})$, arsenic (As), chromium $(\mathrm{Cr})$, cadmium $(\mathrm{Cd})$, zinc $(\mathrm{Zn})$, copper $(\mathrm{Cu})$, boron $(\mathrm{B})$, manganese $(\mathrm{Mn})$, cobalt $(\mathrm{Co})$, and molybdenum $(\mathrm{Mo})$, many of which are toxic to crop plants, animals, and humans [30]. Prolonged consumption of foods and vegetables grown from unsafe wastewater with high concentrations of heavy metals can cause potential health risks in humans [30]. Plants cultivated in wastewater-irrigated soils exhibit higher concentrations of heavy metals $(\mathrm{Cd}, \mathrm{Pb}$, and $\mathrm{Ni})$ in the edible portions compared with plants grown in the reference soil [30,31].

Thus, wastewater should be treated and then reutilized for crop production to solve these problems. Reuse of wastewater at a reasonable rate can enhance plant growth and productivity [32], thereby increasing the economic benefits for growers due to the reduced need for chemical fertilizers because wastewater contains different plant nutrients $[30,33]$. 
Irrigation with treated wastewater (TWW) to agriculture has been increasing rapidly worldwide $[34,35]$ and is highly encouraged as an alternative source of water and nutrients for plant growth and yield, particularly in aid and semi-arid regions. Arid and semi-arid regions are the areas that have unfavorable environmental circumstances, such as low precipitation rate, shortage of freshwater resources, and high temperatures and evapotranspiration. Accordingly, the management of such environments is challenging particularly with climate change concerns. The application of TWW for irrigation helps conserve goodquality water resources and increases environmental performance [35-37]. Accordingly, recycling nutrients through irrigation bioenergy crops with TWW can provide a suitable option to reduce the synthetic fertilizer application into agricultural lands and improve agricultural sustainability because synthetic fertilizers require a high consumption of fossil fuel during their production process [4].

During wastewater treatments, not all nutrients are separated (particularly nitrogen and phosphorus) from wastewater. The TWW contains nutrients such as nitrate (18.1 $\left.\mathrm{mg} \mathrm{L}^{-1}\right), \mathrm{P}\left(5.2 \mathrm{mg} \mathrm{L}^{-1}\right), \mathrm{K}\left(28.5 \mathrm{mg} \mathrm{L}^{-1}\right), \mathrm{Ca}\left(141.8 \mathrm{mg} \mathrm{L}^{-1}\right), \mathrm{Mg}\left(49.32 \mathrm{mg} \mathrm{L}^{-1}\right)$, and $\mathrm{Zn}\left(0.87 \mathrm{mg} \mathrm{L}^{-1}\right)$ [36]. In another investigation, the TWW contained $\mathrm{NH}_{4}{ }^{+}\left(10.02 \mathrm{mg} \mathrm{L}^{-1}\right)$; $\mathrm{NO}_{3}{ }^{-}\left(61.08 \mathrm{mg} \mathrm{L}^{-1}\right) ; \mathrm{PO}_{4}{ }^{3-}\left(8.7 \mathrm{mg} \mathrm{L}^{-1}\right)$, and $\mathrm{K}^{+}\left(46.8 \mathrm{mg} \mathrm{L}^{-1}\right)$ [32]. Maucieri et al. [38]

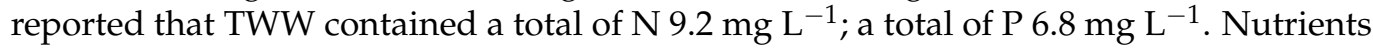
may be present and available to crops irrigated with that water source, thus decreasing plant fertilizer demand $[32,38,39]$. Various crops, such as vetch (Vicia sativa), wheat, barley, and maize irrigated with TWW, show an increase in biological yields $[35,40,41]$. The grain yields of maize, wheat, millet, beans, and rapeseed irrigated with TWW are much higher than those in dry farming, indicating that the TWW can supply essential nutrients to crop plants [33,42]. The crop growth and productivity under wastewater irrigation can be further enhanced if the soil is fertilized with a suitable quantity of chemical fertilizers. Soil nutrient level decreases with the passage of time when crops are continuously grown and harvested. These nutrients are refilled either through natural decomposition or by the addition of fertilizers. Therefore, fertilizers are an essential component of modern agriculture and beneficial to plants in providing deficient nutrients [43,44]. However, their excessive use causes serious environmental problems, such as water soil and air pollution, land degradation, and increased greenhouse gas emissions [43,45]. In general,, chemical fertilizers are applied to increase crop yield, but only $10-40 \%$ of the applied fertilizers can be available to plants [46]. The remaining fertilizers in the soil are lost through leaching and volatilization, which cause a major threat to terrestrial and aquatic environments and affect biodiversity $[47,48]$. High fertilizer amounts, particularly nitrogen, can easily pollute the water table in the instance of heavy rains or in sandy soils. In addition, the nitrous oxide gas that can be emitted for volatilization during field spreading of nitrogenous fertilizers is a key greenhouse gas. Similarly, phosphorus, an essential mineral for plant growth and development $[4,49]$, can cause water pollution [41,50,51]. For example, high rates of phosphorus and nitrogen result in eutrophication by soil erosion due to rain or wind [51].

Thus, judicious use of chemical fertilizers is necessary. Basing on the above background, we hypothesized that reduced application of NPK fertilizers along with TWW increases the aboveground plant biomass and exerts positive effects on plant growth. Therefore, the main objectives of this study are to (1) evaluate the safety of TWW for irrigation of three energy crops fertilized with $100 \%$ or $50 \%$ of the total recommended doses of NPK to maintain the environment and reduce pollution, and (2) cover part of increasing demand for freshwater by using TWW for irrigation of energy crops. In this study, we evaluated the impact of long- and short-term irrigation with TWW on the growth, yield, quality, and energy production of different field crops intended for bioenergy production, compared with groundwater use. This impact was investigated on three field crops, namely, maize, pearl millet, and sorghum. 


\section{Materials and Methods}

\subsection{Preparation, Soil Analysis, and Water Analysis}

To investigate the impact of long- and short-term irrigation with TWW on the growth, biomass, elemental analysis, and energy traits of three crops (maize, sorghum, and pearl millet) fertilized with $50 \%$ and $100 \%$ NPK of the total recommended doses, three experiments were conducted in two locations at the Research Station of the College of Food and Agriculture Sciences, King Saud University, Riyadh, Saudi Arabia $\left(24^{\circ} 25^{\prime} \mathrm{N}, 46^{\circ} 34^{\prime} \mathrm{E}\right.$, $400 \mathrm{~m}$ a.s.l.).

The first location (i.e., old soil) has long been used for cultivation, and it was irrigated with TWW during the last 15 years. The second location was not cultivated for longer than 35 years ago (virgin soil) and was divided into two parts. The first part of this location was irrigated with TWW, whereas the second one was irrigated with groundwater during our investigation. The source of the treated wastewater was obtained from the Southern Plant of Riyadh Wastewater Treatment Plant. Processes used to produce the treated wastewater include activated sludge, trickling filters, and rotating biological contactors, afterward a single tertiary treatment method in the form of sand filters. Domestic and municipal wastewater are the main sources for Wastewater Treatment Plant.

Before sowing, nine soil samples from each location were collected across the different parts to determine the baseline soil physical and chemical properties (Table 1; Figure 1). Each soil sample was collected from three depths $(0-20,20-40$, and $40-60 \mathrm{~cm})$. Thereafter, each soil sample was passed through a $2 \mathrm{~mm}$ sieve and air-dried for $24 \mathrm{~h}$ before analysis. The different soil chemical properties, such as total $\mathrm{N}, \mathrm{P}, \mathrm{K}, \mathrm{Fe}, \mathrm{Mn}, \mathrm{Cu}, \mathrm{Cd}, \mathrm{Pb}, \mathrm{Ni}, \mathrm{Co}$, and $\mathrm{Zn}$, and soil physical properties, such as $\mathrm{EC}, \mathrm{pH}$, organic matter, saturation percentage, and field capacity, were analyzed using the standard methods described by Cottenie et al. [52] and Burt [53]. In addition, the different trace elements of TWW used for irrigation are presented in Table 2. For treated wastewater, physical and macronutrients were $\mathrm{pH} 7.2, \mathrm{EC}$ $1.9 \mathrm{dS} \mathrm{m}^{-1}$, total $\mathrm{N} 23.5 \mathrm{mg} \mathrm{L}^{-1}, \mathrm{NH}_{4}{ }^{+} 2.9 \mathrm{mg} \mathrm{L}^{-1}, \mathrm{NO}_{3}{ }^{-} 5.8 \mathrm{mg} \mathrm{L}^{-1}, \mathrm{PO}_{4}{ }^{3-} 4.1 \mathrm{mg} \mathrm{L}^{-1}$, $\mathrm{K}^{+} 15.7 \mathrm{mg} \mathrm{L}^{-1}, \mathrm{Ca}^{2+} 98.3 \mathrm{mg} \mathrm{L}^{-1}, \mathrm{Mg}^{2+} 30.2 \mathrm{mg} \mathrm{L}^{-1}, \mathrm{Na}^{+} 287.2 \mathrm{mg} \mathrm{L}^{-1}, \mathrm{Cl}^{-} 265.1 \mathrm{mg} \mathrm{L}^{-1}$. The analysis of groundwater was pH 7.36, EC $3.85 \mathrm{dS} \mathrm{m}^{-1}, \mathrm{Ca}^{2+} 217.43 \mathrm{mg} \mathrm{L}^{-1}, \mathrm{Mg}^{2+}$ $126.48 \mathrm{mg} \mathrm{L}^{-1}, \mathrm{Na}^{+} 317.72 \mathrm{mg} \mathrm{L}^{-1}, \mathrm{~K}^{+} 20.33 \mathrm{mg} \mathrm{L}^{-1}$, and $\mathrm{Cl}^{-} 397.39 \mathrm{mg} \mathrm{L}^{-1}$. Water samples were taken at different dates for chemical, physical, and biological analyses during the experiments. The data of weather conditions such as maximum $\left({ }^{\circ} \mathrm{C}\right)$, minimum $\left({ }^{\circ} \mathrm{C}\right)$, and average $\left({ }^{\circ} \mathrm{C}\right)$ temperatures as well as precipitation $(\mathrm{mm})$ and relative humidity $(\%)$ are presented in Table 3.

Table 1. Baseline soil physical and chemical properties for the old cultivated soil and virgin soil two locations prior to sowing.

\begin{tabular}{ccc}
\hline Parameters & Location $\mathbf{1}$ & Locations 2 \\
\hline pH (soil paste 1:5) & 7.83 & 7.95 \\
Saturation percentage $(\%)$ & 28.92 & 23.86 \\
$\mathrm{EC}\left(\mathrm{dS} \mathrm{m}^{-1}\right)$ & 3.67 & 3.73 \\
Organic matter $(\%)_{\mathrm{CaCO}_{3}(\%)} \%$ & 0.41 \\
Field capacity (\%) & 0.48 & 30.92 \\
Wilting point (\%) & 29.01 & 15.18 \\
Sand (\%) & 18.89 & 7.94 \\
Silt (\%) & 7.28 & 58.99 \\
Clay (\%) & 56.70 & 26.50 \\
Texture & 28.40 & 14.51 \\
\hline
\end{tabular}




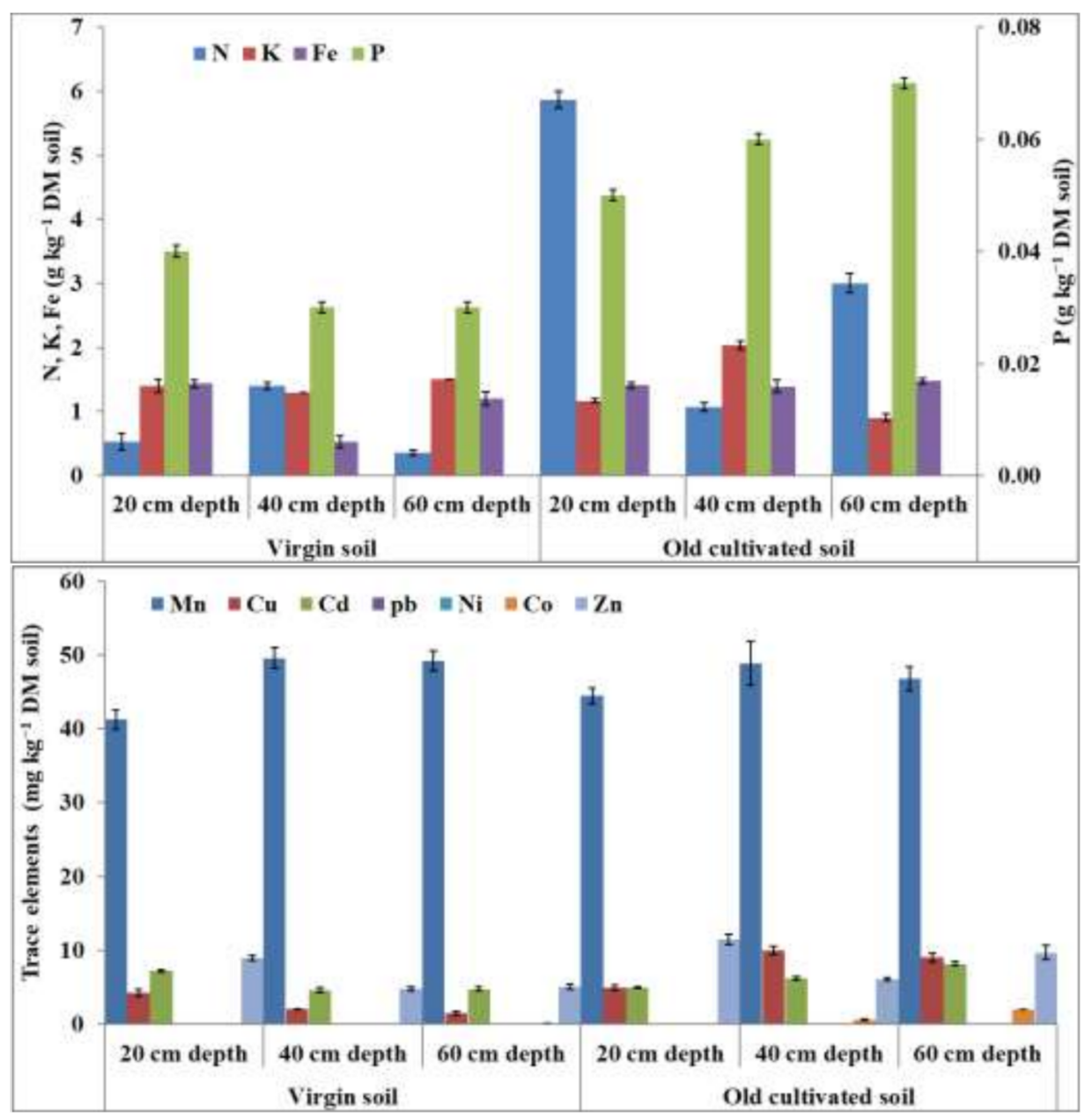

Figure 1. Macro (upper graph) and trace (lower graph) elements of soil prior to sowing for the old cultivated soil and virgin soil at different depths from the topsoil.

Table 2. Global influent and effluent guidelines parameters limits for wastewater and analysis of treated-waste water used in the irrigation of bioenergy crops during the current investigation.

\begin{tabular}{ccccc}
\hline \multirow{2}{*}{ Elements } & \multicolumn{2}{c}{ Limits in Water $\left(\mathbf{m g ~ L}^{-\mathbf{1}}\right)$} & \multicolumn{2}{c}{ Water $\left.\mathbf{m g ~ L}^{-\mathbf{1}}\right)$} \\
\cline { 2 - 5 } & Influent Limit & Final Effluent Limit & Influent to Plant & $\begin{array}{c}\text { Final Effluent to } \\
\text { Plant }\end{array}$ \\
\hline $\mathrm{Cr}$ & 1.20 & 0.10 & 0.005 & $<0.001$ \\
$\mathrm{Cd}$ & 0.02 & 0.01 & $<0.0001$ & $<0.0001$ \\
$\mathrm{Cu}$ & 1.20 & 0.40 & 0.010 & $<0.001$ \\
$\mathrm{~Pb}$ & 1.00 & 0.10 & 0.002 & $<0.001$ \\
$\mathrm{Ni}$ & 2.00 & 0.20 & 0.004 & $<0.001$ \\
$\mathrm{Zn}$ & 2.60 & 4.00 & 0.091 & 0.038 \\
$\mathrm{Al}$ & $\mathrm{ND}$ & 5.00 & 0.465 & 0.030 \\
$\mathrm{~B}$ & 2.00 & 0.75 & 0.610 & 0.605 \\
$\mathrm{Co}$ & $\mathrm{ND}$ & 0.05 & $<0.001$ & $<0.001$ \\
$\mathrm{Fe}$ & $\mathrm{ND}$ & 5.00 & 0.740 & 0.048 \\
$\mathrm{Mn}$ & 5.00 & 0.20 & 0.045 & 0.017 \\
$\mathrm{As}$ & 0.10 & 0.10 & $<0.001$ & $<0.001$ \\
\hline
\end{tabular}


Table 3. Precipitation level and the average of temperatures and relative humidity during the period of the experiment.

\begin{tabular}{|c|c|c|c|c|c|c|}
\hline Months & Parameters & $\begin{array}{l}\text { Precipitation } \\
(\mathrm{mm})\end{array}$ & $\begin{array}{c}\text { Maximum } \\
\text { Temperature }\left({ }^{\circ} \mathrm{C}\right)\end{array}$ & $\begin{array}{c}\text { Minimum } \\
\text { Temperature }\left({ }^{\circ} \mathrm{C}\right)\end{array}$ & $\begin{array}{c}\text { Average } \\
\text { Temperature }\left({ }^{\circ} \mathrm{C}\right)\end{array}$ & $\begin{array}{c}\text { Relative } \\
\text { Humidity (\%) }\end{array}$ \\
\hline \multicolumn{7}{|c|}{ Season 2019} \\
\hline March & & 0.00 & 27.21 & 11.38 & 19.30 & 24.42 \\
\hline April & & 5.13 & 32.45 & 17.25 & 24.85 & 23.78 \\
\hline May & & 0.05 & 37.80 & 23.56 & 30.68 & 20.75 \\
\hline June & & 0.00 & 42.46 & 27.03 & 34.74 & 11.42 \\
\hline July & & 0.00 & 43.04 & 27.06 & 35.05 & 11.64 \\
\hline August & & 0.00 & 42.40 & 26.81 & 34.60 & 13.32 \\
\hline \multicolumn{7}{|c|}{ Long-term 1981-2019 } \\
\hline March & & 2.13 & 28.03 & 12.93 & 20.48 & 22.21 \\
\hline April & & 3.72 & 33.21 & 17.98 & 25.59 & 24.70 \\
\hline May & & 0.84 & 38.62 & 23.00 & 30.81 & 16.55 \\
\hline June & & 0.00 & 41.32 & 24.84 & 33.08 & 10.65 \\
\hline July & & 0.00 & 42.31 & 26.29 & 34.30 & 11.28 \\
\hline August & & 0.04 & 42.16 & 26.43 & 34.30 & 12.71 \\
\hline
\end{tabular}

The long-term data were obtained for the period 1981-2019, except the precipitation was obtained for the period 2000-2019.

\subsection{Sowing Process}

The size of each plot was $16 \mathrm{~m}^{2}(4 \times 4 \mathrm{~m})$. Grains of maize, pearl millet, and sorghum were sown on 25 March 2019. The distance between hills was $20 \mathrm{~cm}$, and that between rows was $50 \mathrm{~cm}$. Three grains were placed in each hill, and thereafter the seedlings were thinned at 18 days after sowing into one plant per hill.

\subsection{Experimental Design and Treatments}

A split-plot in randomized complete block design with four replicates was used in our investigation for the three field experiments of potential bioenergy crops (maize, sorghum, and pearl millet). The main plots were occupied by different water resources, whereas fertilization treatments (50\% and $100 \%$ recommended dose of NPK) were arranged in subplots. The first location (old cultivated soil; L1 + TWW) and the first part of the second location (virgin soil; L2 + TWW) were irrigated with TWW, whereas the second part of the second location was irrigated with groundwater (virgin soil; L3 + GW). The full recommended dose of NPK for each crop was 150-150-60 kg N- $\mathrm{P}_{2} \mathrm{O}_{5}-\mathrm{K}_{2} \mathrm{O}$ ha ${ }^{-1}$ in accordance with the local recommendation. The recommended dose was estimated by the Ministry of Environment, Water and Agriculture, Saudi Arabia, based on the conducting of different investigations in the region as well as based on the requirements of the crops from NPK. The fertilizer used in this study consisted of $18 \% \mathrm{~N}, 18 \% \mathrm{P}_{2} \mathrm{O}_{5}, 5 \% \mathrm{~K}_{2} \mathrm{O}$, and $1.5 \%$ other elements. The amount of each recommended dose of NPK was applied in three doses. The first, second, and third doses of each recommended dose of NPK were $20 \%$, $40 \%$, and $40 \%$ of the total amount of fertilizer and were applied at 25, 45 , and 65 days after sowing, respectively.

\subsection{Measurements}

\subsubsection{Growth and Biomass Measurements}

Plant samples were collected at 100 days after sowing to measure different growth parameters, such as plant height, leaf area per plant, and total chlorophyll. The chlorophyll content of the topmost fully expanded and sun-exposed leaves on the main stem was recorded at 10:00-12:00 am using the SPAD meter (Soil Plant Analysis Development; Model: SPAD-502; Minolta Sensing Ltd., Osaka, Japan) at the flowering stage (i.e., anthesis). SPAD measurements were recorded from five plants within each subplot, and these five measurements were averaged to obtain a single value for each replication.

Five plants from the second row of each plot were randomly collected at 100 days after sowing to measure the plant height (from the soil surface to the plant top; $\mathrm{cm}$ ), the total leaf area per plant $\left(\mathrm{cm}^{2}\right)$, and the total fresh weight and dry weight. Five plants were immediately weighed after being collected to record the fresh weight (FW). Thereafter, all 
green leaves from the five plants were separated and rung through an area meter (LI-3000C, Portable Leaf Area Meter, LI-COR Inc., Lincoln, NE, USA) to measure the surface leaf area. All parts of the five plants (stem, green, and complete brown leaves) were oven-dried at $65{ }^{\circ} \mathrm{C}$ for $72 \mathrm{~h}$ and then weighed to obtain the dry weight (DW).

When different crops reached physiological maturity, an area of $6.0 \mathrm{~m}^{2}$ (three $4-\mathrm{m}$ consecutive middle rows) was harvested from each plot to measure whole plant biomass (biological yield). All parts of the harvested area were mixed and crushed, and represented subsamples were collected and oven-dried at $65{ }^{\circ} \mathrm{C}$ for $72 \mathrm{~h}$. Thereafter, the dried samples were weighed and ground into a fine powder $(0.5 \mathrm{~mm}$ mesh size $)$ and stored at room temperature for analyses of macro and microelements (i.e., trace elements) and energy.

\subsubsection{Elemental Analysis}

Concentrations of macro (i.e., N, P, and K) and trace elements (i.e., Fe, Mn, Cu, Cd, $\mathrm{Pb}, \mathrm{Ni}, \mathrm{Co}$, and $\mathrm{Zn}$ ) were analyzed in ground plant samples of maize, pearl millet, and sorghum as described by Seleiman et al. [54]. Ground plant samples (0.3 g) were weighed into PTFE Teflon tubes (CEM, Matthews, North Carolina, USA). On each sample, a volume of $6 \mathrm{~mL}$ nitric acid $(67 \%)$ and $1 \mathrm{~mL}$ of hydrogen peroxide $(30 \%)$ were added to the plant sample for microwave digestion. The digested samples were filtered through a Whatman paper (grade No. 4, pore size $5 \mu \mathrm{m}$ ). The filtered samples were diluted with distilled water up to $50 \mathrm{~mL}$. Then, the diluted samples were stored at $-20{ }^{\circ} \mathrm{C}$ overnight. Elemental analysis was performed using Inductively Coupled Plasma-Optical Emission Spectrometry (iCAP 6200, Thermo Fisher Scientific, Cambridge, UK).

The total $\mathrm{N}$ in whole plant biomass $(200 \mathrm{mg})$ was analyzed using the Dumas combustion method as described by Seleiman et al. [54].

\subsubsection{Energy Analysis}

The high heating values of maize, pearl millet, and sorghum biomass were analyzed from $500 \mathrm{mg}$ subsamples of ground plant samples by using an adiabatic bomb calorimeter (Parr 1241EA, Parr Instrument Co., Moline, IL, USA) as described by Seleiman et al. [33]. The pellets of benzoic acid (1.0 g, Parr Instrument Co., Moline, IL, USA) were used as standards. Ground biomass samples were compressed into pellets using a Pellet Press (Parr Instrument Co., Moline, IL, USA) prior to the analysis. The higher heating value ( $\mathrm{MJ} \mathrm{kg}^{-1}$ ) was measured through complete combustion with excess $\mathrm{O}_{2}$ at $3.04 \mathrm{MPa}$ in a sealed steel bomb. The gross energy yield for maize, sorghum, and pearl millet was estimated using the following equation:

$$
\text { Gross energy }\left(\mathrm{GJ} \mathrm{ha}^{-1}\right)=\frac{\text { Energy content }\left(\mathrm{MJ} \mathrm{Kg}^{-1}\right) \times \text { Biomass yield }\left(\mathrm{Kg} \mathrm{ha}^{-1}\right)}{1000}
$$

\subsection{Statistical Analysis}

A multivariate ANOVA was carried out to understand the different responses of crops into water resources (i.e., TWW and groundwater) and fertilization treatments (i.e., 50\% and $100 \%$ NPK of the total recommended doses) as individual and interaction factors. A Fisher's protected least significant difference test at 0.05 probability level was used to elucidate the significant differences between the mean values of the treatments. Standard error of means (S.E.M.) was calculated and presented above columns as error bars. Statistical analysis was performed using PASW statistics 21.0 (IBM Inc., Chicago, IL, USA).

\section{Results}

Maize plants grown on old-cultivated soil irrigated with treated wastewater (L1 + TWW) were the tallest $(202.0 \mathrm{~cm})$, followed by plants $(171.75 \mathrm{~cm})$ grown on virgin soil irrigated with treated wastewater (L2 + TWW). Maize plants grown on virgin soil and irrigated with groundwater $(\mathrm{L} 3+\mathrm{GW})$ were the lowest plants $(162.50 \mathrm{~cm})$ (Table 4$)$. A similar trend was recorded in sorghum and pearl millet plants. Both crops produced taller plants (sorghum 
$281.38 \mathrm{~cm}$; pearl millet $163.19 \mathrm{~cm}$ ) when grown on old-cultivated soil and irrigated with TWW, whereas the shortest plants (sorghum $162.56 \mathrm{~cm}$; pearl millet $151.25 \mathrm{~cm}$ ) were obtained on virgin soil irrigated with GW. The individual effect of NPK fertilizer on the height of maize, sorghum, and pearl millet plants was not significant (Table 4).

Table 4. Effects of individual factors of water resources and fertilization treatments on growth and total biomass traits of maize, sorghum, and pearl millet.

\begin{tabular}{|c|c|c|c|c|}
\hline Parameters & Plant Height $(\mathrm{cm})$ & Total Chlorophyll & $\begin{array}{c}\text { Leaf Area Plant } \\
\left(\mathrm{cm}^{-1}\right)\end{array}$ & $\begin{array}{c}\text { Total biomass } \\
\left(\mathrm{t} \mathrm{ha} \mathbf{h}^{-1} \mathrm{DM}\right)\end{array}$ \\
\hline \multicolumn{5}{|c|}{ Maize } \\
\hline \multicolumn{5}{|c|}{ Water sources (LEWS) } \\
\hline $\mathrm{L} 1+\mathrm{TWW}$ & 202.00 & 45.32 & 1564.81 & 36.77 \\
\hline $\mathrm{L} 2+\mathrm{TWW}$ & 171.75 & 32.00 & 1453.60 & 18.47 \\
\hline $\mathrm{L} 3+\mathrm{GW}$ & 162.50 & 33.61 & 1277.91 & 16.06 \\
\hline S.E.M. & 5.56 & 1.99 & 61.36 & 0.44 \\
\hline Significance & $* *$ & $* *$ & $*$ & $* *$ \\
\hline \multicolumn{5}{|c|}{ Fertilization $(F)$} \\
\hline F50 & 175.17 & 33.14 & 1392.99 & 22.89 \\
\hline F100 & 182.33 & 40.82 & 1471.23 & 24.64 \\
\hline S.E.M. & 4.54 & 1.63 & 50.10 & 0.36 \\
\hline Significance & ns & $* *$ & ns & $* *$ \\
\hline \multicolumn{5}{|c|}{ Sorghum } \\
\hline \multicolumn{5}{|c|}{ Water sources (LEWS) } \\
\hline $\mathrm{L} 1+\mathrm{TWW}$ & 281.38 & 51.03 & 1175.92 & 34.54 \\
\hline $\mathrm{L} 2+\mathrm{TWW}$ & 228.88 & 36.04 & 1004.36 & 28.82 \\
\hline $\mathrm{L} 3+\mathrm{GW}$ & 162.56 & 28.72 & 1025.79 & 19.40 \\
\hline S.E.M. & 6.63 & 1.28 & 29.37 & 1.08 \\
\hline Significance & $* *$ & $* *$ & $* *$ & $* *$ \\
\hline \multicolumn{5}{|c|}{ Fertilization $(F)$} \\
\hline F50 & 217.96 & 37.60 & 996.65 & 27.87 \\
\hline F100 & 230.58 & 39.59 & 1140.73 & 27.91 \\
\hline S.E.M. & 5.41 & 1.04 & 23.98 & 0.88 \\
\hline Significance & ns & ns & $* *$ & ns \\
\hline \multicolumn{5}{|c|}{ Pearl millet } \\
\hline \multicolumn{5}{|c|}{ Water sources (LEWS) } \\
\hline $\mathrm{L} 1+\mathrm{TWW}$ & 163.19 & 56.22 & 521.91 & 18.86 \\
\hline $\mathrm{L} 2+\mathrm{TWW}$ & 160.63 & 48.91 & 496.37 & 14.70 \\
\hline $\mathrm{L} 3+\mathrm{GW}$ & 151.25 & 47.58 & 476.48 & 10.70 \\
\hline S.E.M. & 3.13 & 1.72 & 9.05 & 0.44 \\
\hline Significance & $* *$ & $* *$ & $*$ & $* *$ \\
\hline \multicolumn{5}{|c|}{ Fertilization $(F)$} \\
\hline F50 & 154.83 & 47.37 & 497.90 & 14.14 \\
\hline F100 & 161.88 & 54.44 & 498.61 & 15.36 \\
\hline S.E.M. & 2.56 & 1.41 & 18.00 & 0.36 \\
\hline Significance & ns & $*$ & ns & ns \\
\hline
\end{tabular}

S.E.M. = Standard error of means; L1 + TWW = Old soil + Wastewater; L2 + TWW = Virgin soil + Wastewater; L3 + GW = Virgin soil + Groundwater; F50 and F100 are 50\% and 100\% NPK of the total recommended dose, respectively. ns $=$ Probability $(p) \geq 0.05$; ${ }^{*}=p \leq 0.05 ;{ }^{* *}=p \leq 0.01$.

Total chlorophyll content in terms of SPAD values increased in all three tested crops grown on old-cultivated soil and irrigated with TWW (Table 4). In maize and sorghum, the highest total chlorophyll content (45.32 and 51.03 SPAD, respectively) was noted when these crops were grown on old-cultivated soil and irrigated with TWW, followed by those in crops grown on virgin soil with TWW, and the lowest was observed in the crops grown on virgin soil and irrigated with GW. In pearl millet, the total chlorophyll content in plants grown on old soil and irrigated with TWW was higher by $15.4 \%$ or $13.0 \%$ than those obtained from plants grown on virgin soil irrigated with GW or TWW, respectively. The 
individual effect of NPK fertilizer doses was significant in maize and pearl millet but not in sorghum crop. Application of $100 \%$ recommended dose of NPK considerably increased the total chlorophyll content in maize and pearl millet (40.82 and 54.44 SPAD, respectively) compared with 50\% recommended dose of NPK (33.14 and 47.37 SPAD, respectively).

Likewise, leaf area plant ${ }^{-1}$ significantly increased in the maize $\left(1564.81 \mathrm{~cm}^{2}\right)$, sorghum $\left(1175.92 \mathrm{~cm}^{2}\right)$, and pearl millet $\left(521.91 \mathrm{~cm}^{2}\right)$ by $18.33,12.76$, and $8.70 \%$ when grown on old-cultivated soil and irrigated with TWW compared to those grown on virgin soil and irrigated with GW, respectively (Table 4). The leaf area of maize and pearl millet plants grown on virgin soil and irrigated with TWW was higher than those of plants grown on virgin soil and irrigated with GW. However, there were no significant differences between the leaf area obtained from sorghum plants grown on virgin soil and irrigated with TWW or GW (Table 4). The individual effect of NPK fertilizer was not significant for maize and pearl millet, but it significantly influenced sorghum leaf area (Table 4). Application of $100 \%$ recommended dose of NPK fertilizer enhanced the leaf area plant ${ }^{-1}\left(1140.73 \mathrm{~cm}^{2}\right)$ in sorghum by $12.63 \%$ as compared with $50 \%$ recommended dose of NPK $\left(996.65 \mathrm{~cm}^{2}\right)$. The interactive effect of NPK fertilizer with soil locations and irrigation sources was analyzed. With the application of $50 \%$ or $100 \%$ recommended NPK dose, the largest leaf area was observed in the maize, sorghum, and pearl millet grown on old soil and irrigated with treated wastewater, followed by those in the crops grown virgin soil irrigated with TWW, and the smallest was noted in the crops grown on virgin soil and irrigated with GW (Table 5).

Table 5. Interaction effects of water resources and fertilization treatments on leaf area per plant and total biomass of maize, sorghum, and pearl millet.

\begin{tabular}{|c|c|c|c|}
\hline Treatments & Parameters & $\begin{array}{l}\text { Leaf area Plant } \\
\left(\mathrm{cm}^{2}\right)\end{array}$ & $\begin{array}{c}\text { Total Biomass } \\
\text { (t ha }{ }^{-1} \text { DM) }\end{array}$ \\
\hline \multicolumn{4}{|c|}{$\overline{\text { Maize }}$} \\
\hline \multirow[t]{2}{*}{$\mathrm{L} 1+\mathrm{TWW}$} & F50 & 1473.26 & 36.03 \\
\hline & F100 & 1656.36 & 37.50 \\
\hline \multirow[t]{2}{*}{$\mathrm{L} 2+\mathrm{TWW}$} & F50 & 1382.94 & 17.39 \\
\hline & F100 & 1524.27 & 19.54 \\
\hline \multirow[t]{2}{*}{$\mathrm{L} 3+\mathrm{GW}$} & F50 & 1322.77 & 15.25 \\
\hline & F100 & 1233.05 & 16.86 \\
\hline S.E.M. & & 42.00 & 0.63 \\
\hline \multirow[t]{2}{*}{ Significance } & & $* *$ & $* *$ \\
\hline & \multicolumn{3}{|c|}{ Sorghum } \\
\hline \multirow[t]{2}{*}{$\mathrm{L} 1+\mathrm{TWW}$} & F50 & 1096.62 & 34.44 \\
\hline & F100 & 1255.22 & 34.64 \\
\hline \multirow[t]{2}{*}{$\mathrm{L} 2+\mathrm{TWW}$} & F50 & 934.03 & 28.16 \\
\hline & F100 & 1074.70 & 29.48 \\
\hline \multirow[t]{2}{*}{$\mathrm{L} 3+\mathrm{GW}$} & F50 & 959.30 & 19.20 \\
\hline & F100 & 1092.27 & 19.60 \\
\hline S.E.M. & & 35.00 & 0.50 \\
\hline \multirow[t]{2}{*}{ Significance } & & $* *$ & $* *$ \\
\hline & \multicolumn{3}{|c|}{ Pearl millet } \\
\hline \multirow[t]{2}{*}{ L1 + TWW } & F50 & 517.96 & 18.82 \\
\hline & F100 & 525.86 & 18.89 \\
\hline \multirow[t]{2}{*}{$\mathrm{L} 2+\mathrm{TWW}$} & F50 & 515.05 & 14.48 \\
\hline & F100 & 532.05 & 14.93 \\
\hline \multirow[t]{2}{*}{$\mathrm{L} 3+\mathrm{GW}$} & F50 & 437.91 & 9.13 \\
\hline & F100 & 460.69 & 12.26 \\
\hline S.E.M. & & 31.18 & 0.23 \\
\hline Significance & & $* *$ & $* *$ \\
\hline
\end{tabular}

S.E.M. = Standard error of means; L1 + TWW = Old soil + Wastewater; L2 + TWW = Virgin soil + Wastewater $\mathrm{L} 3+\mathrm{GW}=$ Virgin soil + Groundwater; F50 and F100 are 50\% and 100\% NPK of the total recommended dose, respectively. ${ }^{*}=$ Probability $(p) \leq 0.05 ;{ }^{* *}=p \leq 0.01$. 
Plantation of maize on old-cultivated soil and irrigated with TWW resulted in higher biomass by $56.32 \%$ and $50.23 \%$ than those grown on virgin soil and irrigated with GW and TWW, respectively (Table 4). Likewise, sorghum and pearl millet produced higher biomass (43.83 and $56.73 \%$, respectively) when grown on old-cultivated soil and irrigated with TWW rather than when grown on virgin soil and irrigated with GW. Use of $100 \%$ recommended dose of NPK fertilizer significantly increased the biomass in maize $\left(24.64 \mathrm{t} \mathrm{ha}^{-1}\right)$ by $7.1 \%$ compared with $50 \%$ recommended dose of NPK fertilizer ( $22.89 \mathrm{t} \mathrm{ha}^{-1}$ ); however, NPK doses exerted no significant effect on the dry biomass of sorghum and pearl millet (Table 4). Interaction of NPK fertilizer with soil locations and irrigation sources exhibited that use of $50 \%$ or $100 \%$ recommended dose of NPK in old-soil irrigated with TWW resulted in higher biomass in crops (maize, sorghum, and pearl millet) followed by virgin soil irrigated with TWW (Table 5) compared with those grown on virgin soil and irrigated with GW.

Maize, sorghum, and pearl millet grown on old-cultivated soil and irrigated with TWW possessed higher energy content $\left(16.87,17.54\right.$, and $16.11 \mathrm{MJ} \mathrm{kg}^{-1} \mathrm{DM}$, respectively), followed by virgin soil irrigated with TWW, and lower energy content from these crops were recorded when grown on virgin soil irrigated with GW $(16.41,15.53$, and $15.53 \mathrm{MJ} \mathrm{kg}^{-1} \mathrm{DM}$, respectively), (Table 6). The individual effect of NPK fertilizer on the energy content of all crops was not significant. In the case of gross energy, maize (620.30 $\mathrm{GJ} \mathrm{ha}^{-1}$ ), sorghum (605.83 $\mathrm{GJ} \mathrm{ha}^{-1}$ ), and pearl millet (303.83 $\mathrm{GJ} \mathrm{ha}^{-1}$ ) showed higher gross energy value when grown on old-cultivated soil and irrigated with TWW, whereas minimum gross energy $\left(263.54,301.28\right.$, and $166.17 \mathrm{GJ} \mathrm{ha}^{-1}$, respectively) was observed when they were grown on virgin soil irrigated with GW. This means that gross energy obtained from maize, sorghum, and pearl millet grown in old-cultivated soil and irrigated with TWW was increased by 57.51, 50.26, and $45.30 \%$ compared with those grown on virgin soil irrigated with GW, respectively. The individual effect of NPK fertilizer on gross energy in maize was significant but not in sorghum and pearl millet crops. Higher gross energy was recorded from maize $\left(409.02 \mathrm{GJ} \mathrm{ha}^{-1}\right)$ when a $100 \%$ recommended dose of NPK fertilizer was applied as compared with a 50\% recommended dose of NPK fertilizer (383.86 GJ ha ${ }^{-1}$ ). The highest ash content (maize 12.02\%, sorghum $9.92 \%$, and pearl millet $15.61 \%$ ) was recorded when the crops were cultivated on virgin soil and irrigated with GW, followed by crops cultivated on virgin soil irrigated with TWW, and the lowest ash content for the same crops $(9.24 \%, 7.54 \%$, and $13.49 \%)$ was recorded when they were sown on old-cultivated soil and irrigated with TWW. The individual effect of NPK fertilizer dose on the ash content of crops was not significant (Table 6).

Table 6. Effects of individual factors of water resources and fertilization treatments on energy and ash traits of maize, sorghum, and pearl millet.

\begin{tabular}{|c|c|c|c|}
\hline Treatments & $\begin{array}{c}\text { Energy Content } \\
\left.\text { (MJ kg }{ }^{-1} \mathrm{DM}\right)\end{array}$ & $\begin{array}{c}\text { Gross Energy } \\
\left(G J \mathrm{ha}^{-1}\right)\end{array}$ & Ash Content (\%) \\
\hline \multicolumn{4}{|c|}{ Maize } \\
\hline \multicolumn{4}{|c|}{ Water sources (LEWS) } \\
\hline $\mathrm{L} 1+\mathrm{TWW}$ & 16.87 & 620.30 & 9.24 \\
\hline $\mathrm{L} 2+\mathrm{TWW}$ & 16.77 & 309.74 & 10.23 \\
\hline $\mathrm{L} 3+\mathrm{GW}$ & 16.41 & 263.54 & 12.02 \\
\hline S.E.M. & 0.12 & 8.36 & 0.55 \\
\hline Significance & * & $* *$ & * \\
\hline \multicolumn{4}{|c|}{ Fertilization $(F)$} \\
\hline F50 & 16.77 & 383.86 & 11.04 \\
\hline F100 & 16.60 & 409.02 & 9.96 \\
\hline S.E.M. & 0.10 & 6.82 & 0.45 \\
\hline Significance & ns & $* *$ & ns \\
\hline
\end{tabular}


Table 6. Cont.

\begin{tabular}{|c|c|c|c|}
\hline Parameters & $\begin{array}{l}\text { Energy Content } \\
\left.\text { (MJ kg }{ }^{-1} \mathrm{DM}\right)\end{array}$ & $\begin{array}{l}\text { Gross Energy } \\
\left(\mathrm{GJ} \mathrm{ha}^{-1}\right)\end{array}$ & Ash Content (\%) \\
\hline \multicolumn{4}{|c|}{ Sorghum } \\
\hline \multicolumn{4}{|c|}{ Water sources (LEWS) } \\
\hline $\mathrm{L} 1+\mathrm{TWW}$ & 17.54 & 605.83 & 7.54 \\
\hline $\mathrm{L} 2+\mathrm{TWW}$ & 15.94 & 459.39 & 9.47 \\
\hline $\mathrm{L} 3+\mathrm{GW}$ & 15.53 & 301.28 & 9.92 \\
\hline S.E.M. & 0.11 & 18.75 & 0.28 \\
\hline Significance & $* *$ & $* *$ & $* *$ \\
\hline \multicolumn{4}{|c|}{ Fertilization $(F)$} \\
\hline F50 & 16.36 & 446.13 & 9.00 \\
\hline F100 & 16.32 & 455.49 & 8.95 \\
\hline S.E.M. & 0.09 & 15.31 & 0.23 \\
\hline Significance & ns & ns & ns \\
\hline \multicolumn{4}{|c|}{ Pearl millet } \\
\hline \multicolumn{4}{|c|}{ Water sources (LEWS) } \\
\hline $\mathrm{L} 1+\mathrm{TWW}$ & 16.11 & 303.83 & 13.49 \\
\hline $\mathrm{L} 2+\mathrm{TWW}$ & 15.94 & 234.31 & 14.33 \\
\hline $\mathrm{L} 3+\mathrm{GW}$ & 15.53 & 166.17 & 15.61 \\
\hline S.E.M. & 0.11 & 7.58 & 0.37 \\
\hline Significance & $* *$ & $* *$ & $* *$ \\
\hline \multicolumn{4}{|c|}{ Fertilization $(F)$} \\
\hline F50 & 15.84 & 223.97 & 14.52 \\
\hline F100 & 15.88 & 243.91 & 14.43 \\
\hline S.E.M. & 0.09 & 12.19 & 0.30 \\
\hline Significance & ns & ns & ns \\
\hline
\end{tabular}

S.E.M. = Standard error of means; L1 + TWW = Old soil + Wastewater; L2 + TWW = Virgin soil + Wastewater L3 + GW = Virgin soil + Groundwater; F50 and F100 are 50\% and 100\% NPK of the total recommended dose, respectively. ns $=$ Probability $(p) \geq 0.05 ;{ }^{*}=p \leq 0.05 ;{ }^{* *}=p \leq 0.01$.

The interactive effect of irrigation water sources and different doses of NPK showed that irrigation with TWW and fertilization with a 50\% recommended dose of NPK resulted in higher gross energy values of maize (610.41 GJ ha $\left.{ }^{-1}\right)$, sorghum $\left(604.29 \mathrm{GJ} \mathrm{ha}^{-1}\right)$, and pearl millet (301.13) than irrigation with GW and fertilization with 100\% recommended dose of NPK $\left(274.58,302.62\right.$, and $189.40 \mathrm{GJ} \mathrm{ha}^{-1}$, respectively), (Table 7). However, the energy content was higher in maize (16.94 $\left.\mathrm{MJ} \mathrm{kg}^{-1} \mathrm{DM}\right)$ and sorghum (17.56 $\left.\mathrm{MJ} \mathrm{kg}^{-1} \mathrm{DM}\right)$ irrigated with TWW and fertilized with 50\% recommended dose of NPK fertilizer in old soil than in the crops irrigated with GW and fertilized with $100 \%$ recommended dose of NPK fertilizer in virgin soil (16.28 and $15.44 \mathrm{MJ} \mathrm{kg}^{-1} \mathrm{DM}$, respectively). However, pearl millet produced higher energy content (16.21 $\left.\mathrm{MJ} \mathrm{kg}^{-1} \mathrm{DM}\right)$ when irrigated with TWW and fertilizer with $100 \%$ recommended dose of NPK than when irrigated with GW and 100\% recommended dose of NPK (15.44 $\left.\mathrm{MJ} \mathrm{kg}^{-1} \mathrm{DM}\right)$.

Interaction effects of NPK fertilizer and soil with irrigation sources on macronutrients, such as nitrogen $(\mathrm{N})$, phosphorus $(\mathrm{P})$, and potassium $(\mathrm{K})$, in maize, sorghum, and pearl millet plants were significant (Table 8). Results showed that the biomass of different crops contained the highest nutrients when grown on old- soil irrigated with TWW, followed by virgin soil irrigated with TWW, and the lowest nutrients were recorded in crops grown on virgin soil irrigated with GW (Table 8 and Figure 2). Maize crop cultivated on old-soil irrigated with TWW and fertilized with $100 \%$ or $50 \%$ recommended dose of NPK showed the highest $\mathrm{N}$ (23.0 and $\left.21.0 \mathrm{~g} \mathrm{~kg}^{-1} \mathrm{DM}\right)$ and $\mathrm{P}$ content $\left(2.1\right.$ and $\left.2.0 \mathrm{~g} \mathrm{~kg}^{-1} \mathrm{DM}\right)$ compared with virgin soil irrigated with GW and fertilized with $100 \%$ or $50 \%$ recommended dose of NPK (7.9 and $5.0 \mathrm{~g} \mathrm{~kg}^{-1} \mathrm{DM}$ for $\mathrm{N} ; 1.5$ and $1.2 \mathrm{~g} \mathrm{~kg}^{-1} \mathrm{DM}$ for P, respectively). A similar trend was recorded in sorghum and pearl millet plants, where $\mathrm{N}$ and $\mathrm{P}$ contents were higher in biomass cultivated on old soil irrigated with TWW and fertilized with 100\% or $50 \%$ recommended dose of NPK than in biomass cultivated on virgin soil irrigated with 
TWW or virgin soil irrigated with GW. Similarly, the K contents in maize $\left(15.18 \mathrm{~g} \mathrm{~kg}^{-1} \mathrm{DM}\right)$, sorghum (19.85 $\left.\mathrm{g} \mathrm{kg}^{-1} \mathrm{DM}\right)$, and pearl millet $\left(16.10 \mathrm{~g} \mathrm{~kg}^{-1} \mathrm{DM}\right)$ increased when grown on old-cultivated soil with TWW and applied with $100 \%$ recommended dose of NPK without significant differences with 50\% recommended dose of NPK compared with the virgin soil irrigated with TWW or GW along with the recommended doses of NPK (Table 8). However, the interaction effect of NPK fertilizer doses (50\% and 100\% recommended dose) on sorghum or pearl millet irrigated with TWW or GW was not significant for the content of $\mathrm{K}$ in biomass.

Table 7. Interaction effects of water resources and fertilization treatments on energy traits of maize, sorghum, and pearl millet.

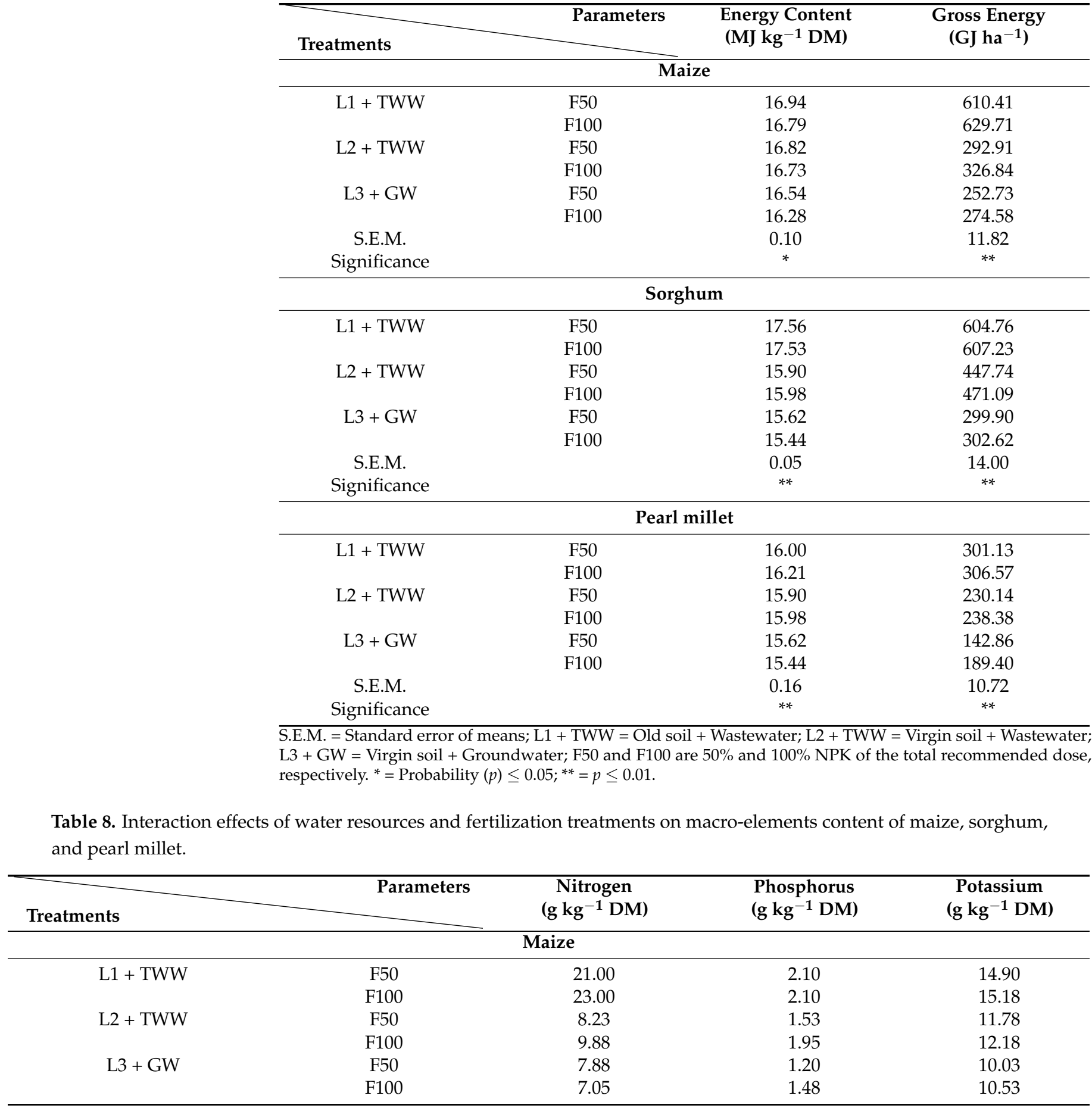

Table 8. Interaction effects of water resources and fertilization treatments on macro-elements content of maize, sorghum, and pearl millet. 
Table 8. Cont.

\begin{tabular}{|c|c|c|c|c|}
\hline Treatments & Parameters & $\begin{array}{c}\text { Nitrogen } \\
\left(\mathrm{g} \mathrm{kg}^{-1} \mathrm{DM}\right)\end{array}$ & $\begin{array}{l}\text { Phosphorus } \\
\text { (g kg }^{-1} \text { DM) }\end{array}$ & $\begin{array}{c}\text { Potassium } \\
\left(\mathrm{g} \mathrm{kg}^{-1} \mathrm{DM}\right)\end{array}$ \\
\hline S.E.M. & & 0.29 & 0.04 & 0.32 \\
\hline Significance & & $* *$ & $* *$ & $* *$ \\
\hline \multicolumn{5}{|c|}{ Sorghum } \\
\hline \multirow[t]{2}{*}{ L1 + TWW } & F50 & 10.18 & 1.83 & 17.00 \\
\hline & F100 & 13.33 & 1.95 & 19.85 \\
\hline \multirow[t]{2}{*}{$\mathrm{L} 2+\mathrm{TWW}$} & F50 & 9.28 & 1.44 & 10.03 \\
\hline & F100 & 12.23 & 1.58 & 11.63 \\
\hline \multirow[t]{2}{*}{$\mathrm{L} 3+\mathrm{GW}$} & F50 & 7.05 & 1.19 & 8.43 \\
\hline & F100 & 10.60 & 1.28 & 8.95 \\
\hline S.E.M. & & 0.21 & 0.04 & 0.42 \\
\hline \multirow[t]{2}{*}{ Significance } & & $* *$ & $* *$ & $* *$ \\
\hline & & 1 millet & & \\
\hline \multirow[t]{2}{*}{ L1 + TWW } & F50 & 9.10 & 1.65 & 15.60 \\
\hline & F100 & 12.13 & 1.88 & 16.10 \\
\hline \multirow[t]{2}{*}{$\mathrm{L} 2+\mathrm{TWW}$} & F50 & 9.10 & 1.51 & 11.08 \\
\hline & F100 & 10.03 & 1.61 & 10.95 \\
\hline \multirow{2}{*}{$\mathrm{L} 3+\mathrm{GW}$} & F50 & 8.25 & 1.11 & 7.05 \\
\hline & F100 & 8.35 & 1.35 & 7.50 \\
\hline S.E.M. & & 0.27 & 0.08 & 0.24 \\
\hline Significance & & $* *$ & $* *$ & $* *$ \\
\hline
\end{tabular}

S.E.M. = Standard error of means; L1 + TWW = Old soil + Wastewater; L2 + TWW = Virgin soil + Wastewater; $\mathrm{L} 3+\mathrm{GW}=$ Virgin soil + Groundwater; F50 and F100 are 50\% and 100\% NPK of the total recommended dose, respectively. ns $=$ Probability $(p) \geq 0.05$; ${ }^{*}=p \leq 0.05 ;{ }^{* *}=p \leq 0.01$.

The application of NPK fertilizer and soil locations with irrigation sources affected the trace elements (i.e., $\mathrm{Mn}, \mathrm{Cu}, \mathrm{Zn}, \mathrm{Fe}, \mathrm{Pb}, \mathrm{Ni}, \mathrm{Co}$, and $\mathrm{Cd}$ ) in plant biomasses (maize, sorghum, and pearl millet) (Figures 2 and 3). Mn content increased in maize $\left(16.40 \mathrm{mg} \mathrm{kg}^{-1} \mathrm{DM}\right)$, sorghum (18.50 $\left.\mathrm{mg} \mathrm{kg}^{-1} \mathrm{DM}\right)$, and pearl millet $\left(20.0 \mathrm{mg} \mathrm{kg}^{-1} \mathrm{DM}\right)$ plants grown on old-soil and virgin irrigated with TWW and fertilized with 50\% recommended dose of NPK than virgin soil irrigated with GW $\left(14.95,16.25\right.$, and $14.23 \mathrm{mg} \mathrm{kg}^{-1} \mathrm{DM}$, respectively). However, the highest Mn content in maize, sorghum, and pearl millet was recorded when these crops were grown on virgin soil irrigated with TWW and fertilized with 100\% recommended dose of NPK fertilizer (18.50, 24.05, and $20.78 \mathrm{mg} \mathrm{kg}^{-1} \mathrm{DM}$, respectively). Aside from these results, fertilizer doses exerted no significant effect on $\mathrm{Mn}$ content in plants grown on old soil irrigated with TWW and virgin soil irrigated with GW.

The concentrations of $\mathrm{Cu}$ and $\mathrm{Zn}$ showed no significant differences in maize, sorghum, and pearl millet plants grown on old-cultivated soil irrigated with TWW or on virgin soil irrigated with TWW (Figure 2). However, maize plants grown on old and virgin soils irrigated with TWW had higher $\mathrm{Cu}$ (17.95 and $17.15 \mathrm{mg} \mathrm{kg}^{-1} \mathrm{DM}$, respectively) content than the plants grown on virgin soil irrigated with GW (12.98 $\left.\mathrm{mg} \mathrm{kg}^{-1} \mathrm{DM}\right)$. Meanwhile, higher $\mathrm{Cu}$ content was noted when sorghum and pearl millet plants were grown on virgin soil irrigated with GW and used 50\% recommended dose of NPK. Similarly, Fe content significantly increased in sorghum $\left(29.75 \mathrm{mg} \mathrm{kg}^{-1} \mathrm{DM}\right)$ and pearl millet $\left(17.10 \mathrm{mg} \mathrm{kg}^{-1}\right.$ DM) grown on old soil and virgin soil irrigated TWW and used $100 \%$ recommended dose of NPK than in the plants grown on virgin soil irrigated with GW. However, the highest Fe content $\left(49.65 \mathrm{mg} \mathrm{kg}^{-1} \mathrm{DM}\right)$ was noted in maize plants sown on virgin soil irrigated with TWW, followed by maize plants sown on old soil irrigated with treated wastewater, and the lowest was found in maize plants grown on virgin soil and irrigated with GW (Figure 2). Effect of NPK fertilizer doses with soil location and irrigation sources showed that application of 50\% recommended dose of NPK effectively increased Fe content in plants, except in maize where $100 \%$ recommended dose of NPK fertilizer enhanced Fe uptake. 

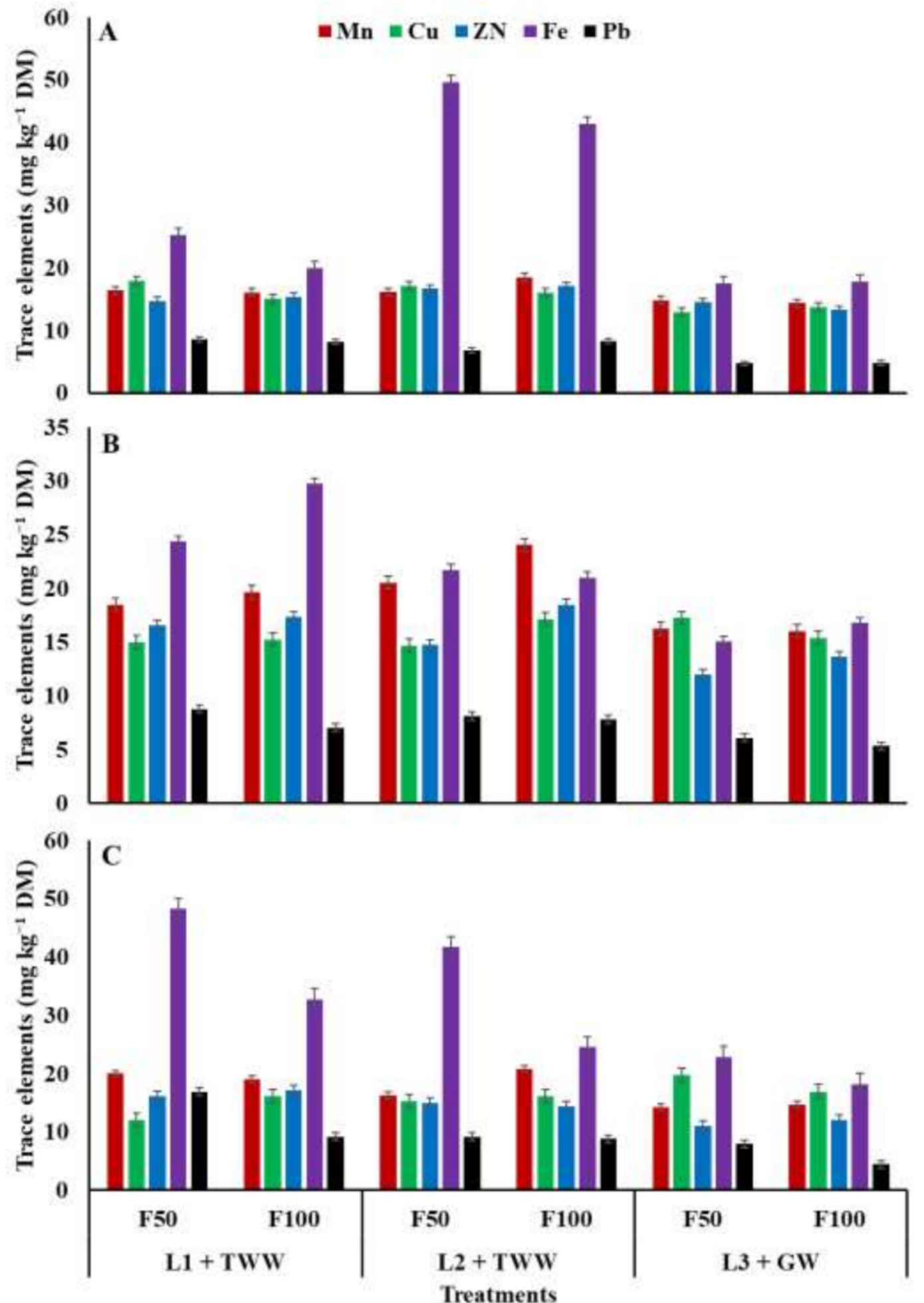

Figure 2. Interaction effects of water resources and fertilization treatments on five trace elements in maize (A), sorghum (B) and pearl millet (C). Error bars $=$ Standard error of means (S.E.M.). L1 + TWW = Old soil + Wastewater; L2 + TWW $=$ Virgin soil + Wastewater; L3 + GW = Virgin soil + Groundwater; F50 and F100 are 50\% and 100\% NPK of the total recommended dose, respectively. 


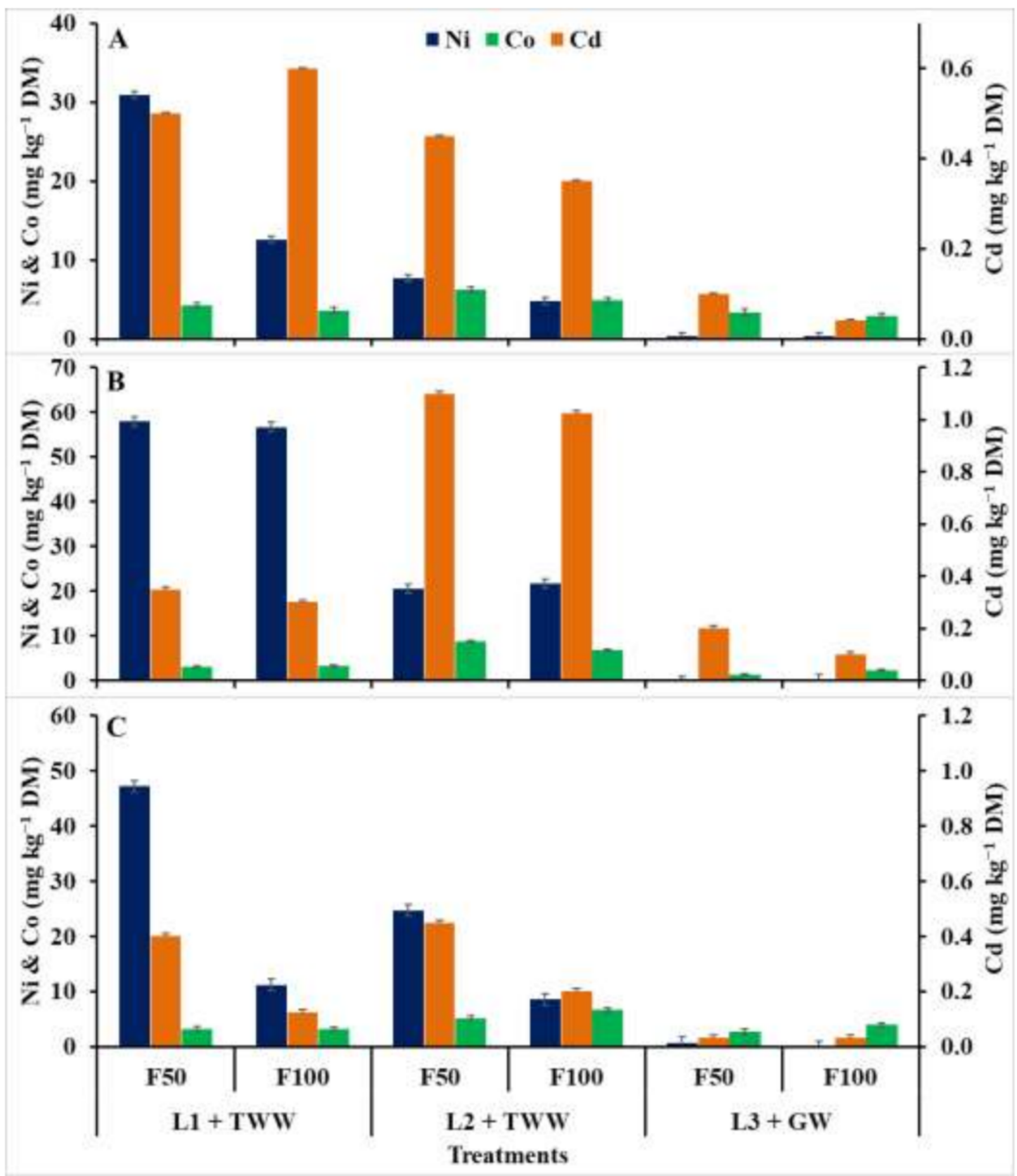

Figure 3. Interaction effects of water resources and fertilization treatments on $\mathrm{Ni}$, Co, and Cd in maize (A), sorghum (B), and pearl millet (C). Error bars = Standard error of means (S.E.M.). L1 + TWW = Old soil + Wastewater; $\mathrm{L} 2+\mathrm{TWW}=\mathrm{Virgin}$ soil + Wastewater; L3 + GW = Virgin soil + Groundwater; F50 and F100 are 50\% and 100\% NPK of the total recommended dose, respectively.

Similarly, $\mathrm{Pb}$ content was higher in the crops grown on old soil and virgin soil irrigated with TWW and fertilized with $50 \%$ or $100 \%$ recommended dose of NPK fertilizer than in the crops grown on virgin soil irrigated with GW (Figure 2). The individual effect of NPK fertilizer dose showed not much variation for $\mathrm{Pb}$ content in plant biomass. The content of Ni significantly increased in the plant biomass of all the crops (maize, sorghum, and pearl millet) grown on old soil irrigated with TWW and fertilized with $50 \%$ or $100 \%$ rec- 
ommended dose of NPK fertilizer followed by virgin soil irrigated with TWW. However, only a small quantity of $\mathrm{Ni}$ was noted in maize, sorghum, and pearl millet plant biomass planted on virgin soil irrigated with GW (Figure 3). The individual effect of NPK fertilizer indicated that application of 50\% recommended dose of NPK fertilizer enhanced the Ni content significantly in maize and pearl millet, but it did not exert a significant effect on sorghum plants.

Similarly, Cd content was higher in the plant biomass of maize, sorghum, and pearl millet sown on whether old or virgin soil irrigated TWW along with $50 \%$ and $100 \%$ recommended dose of NPK fertilizer, whereas a minimum quantity of Cd was measured in plants cultivated on virgin soil irrigated with GW. Overall, the application of a 50\% recommended dose of NPK fertilizer increased the Cd content in plant biomass compared with the $100 \%$ recommended dose of NPK. The plant analysis for Co showed that Co content was higher in plant biomass (maize, sorghum, and pearl millet) grown on virgin soil irrigated with TWW and fertilized with $50 \%$ or $100 \%$ recommended dose of NPK fertilizer than in plant biomass grown on virgin soil irrigated with GW and old-soil irrigated with TWW.

\section{Discussion}

Plant height, leaf area, and dry biomass of maize, sorghum, and pearl millet plants were significantly higher when planted on old and/or virgin soil irrigated with treated wastewater (TWW) than when planted on virgin soil irrigated with groundwater (GW). Furthermore, 50\% recommended dose of NPK with TWW showed equivalent results regarding most of growth and biomass traits to $100 \%$ recommended dose of NPK fertilizer in all crops. This result suggests that TWW can supply enough necessary nutrients that enable plant growth to achieve plant height. The constant availability of essential nutrients, such as N, P, K, Ca, Mg, and other micronutrients, through TWW [55] plays an important role in improving the height, leaf area, and dry biomass of maize, sorghum, and pearl millet. For example, phosphorus is the main constituent of DNA and RNA structures and helps in root growth and development, flower initiation, and seed development. Similarly, potassium activates many enzymes involved in the metabolism of plants and controls the opening and closing of leaf stomata. Thus, potassium is an important nutrient for plant growth. Similarly, calcium plays a key role in the synthesis of the cell wall and its plasticity, and indirectly assists in enhancing plant yields and biomass by decreasing soil acidity. Magnesium is an important content of chlorophyll molecules and therefore is actively involved in plant photosynthesis. TWW irrigation increases the uptake of essential nutrients, such as $\mathrm{K}^{+}, \mathrm{PO}_{4}{ }^{3-}, \mathrm{Cu}^{2+}$, and $\mathrm{Zn}^{2+}$, in plants and improves the growth of fenugreek (Trigonella foenum L.) and corn mint (Mentha arvensis L.) [56]. Such nutrients can play a vital role in various physiological mechanisms of plants, including growth and development, membrane stability, osmotic adjustment, and cellular turgor [57,58]. Mousavi et al. [59] reported that TWW increases the nutrients in soil solution, thereby increasing the leaf area index, dry matter, protein percentage, and $\mathrm{Zn}$ and $\mathrm{P}$ contents of maize plants. Hence, the increase in plant height, leaf area, and dry biomass of crop plants was due to better growth of plants because of the appropriate quantity of nutrients presented in TWW (i.e., total $\mathrm{N} 23.5 \mathrm{mg} \mathrm{L}^{-1}, \mathrm{NH}_{4}{ }^{+} 2.9 \mathrm{mg} \mathrm{L}^{-1}, \mathrm{NO}_{3}{ }^{-} 5.8 \mathrm{mg} \mathrm{L}^{-1}, \mathrm{PO}_{4}{ }^{3-}$ $\left.4.1 \mathrm{mg} \mathrm{L}^{-1}, \mathrm{~K}^{+} 15.7 \mathrm{mg} \mathrm{L}^{-1}\right)$. The water required for growing maize or sorghum or millet in the region of the current study is ranged from $8000-9000 \mathrm{~m}^{3} \mathrm{ha}^{-1}$. Based on the water requirements and nutrients contents in TWW used in our study, TWW can provide a total $\mathrm{N} 188.0-211.5 \mathrm{~kg} \mathrm{ha}^{-1} ; \mathrm{NH}_{4}^{+} 23.2-26.1 \mathrm{~kg} \mathrm{ha}^{-1} ; \mathrm{NO}_{3}^{-} 46.4-52.2 \mathrm{~kg} \mathrm{ha}^{-1} ; \mathrm{PO}_{4}{ }^{3-}$ $32.8-39.7 \mathrm{~kg} \mathrm{ha}^{-1}$; and $\mathrm{K}^{+} 125.6-141.3 \mathrm{~kg} \mathrm{ha}^{-1}$. On the other hand, improving biomass of different crops in the current study when irrigated with TWW, clearly indicates that TWW did not cause stress through the heavy metals which can cause a reduction in the growth and biomass of crops. Similarly, El-Nahhal et al. [60] reported that the plant height and fresh biomass of Chinese cabbage and maize are significantly higher when irrigated with TWW than with fresh water. Zema et al. [61] showed that the application of TWW increases plant height by $25.6 \%$, leaf area index by $86.7 \%$, and biomass yield by $63 \%$ compared with 
the conventional water. Moreover, irrigation with TWW increases plant height and growth in tomato (Solanum lycopersicum Mill.) [62] and pepper (Capiscum annuum L.) [63].

The dry matter of plants increases with increasing leaf area and plant height, providing a large surface for the interception of solar radiation and thus high photosynthetic rate, which increases dry matter accumulation. Plant growth largely depends on nutrients present in the soil, and their deficiency can limit growth, biomass, and productivity [64]. The quantity of nutrients, such as $\mathrm{N}, \mathrm{P}, \mathrm{K}, \mathrm{Cu}, \mathrm{Zn}$, and $\mathrm{Fe}$, was greater in plants irrigated with TWW than in those irrigated with GW (Table 8 and Figure 2), which indicates that TWW had higher nutrients. This can be due to the proper availability of nutrients into crops as a result of TWW and synthetic fertilizer. In addition, TWW in the current study contained higher nitrate than ammonium which can be rapidly uptake by crops. This phenomenon can enhance plants to achieve better growth and development. Therefore, using TWW can be a type of fertigation, which subsequently provides nutrients and enhances the photosynthesis, growth, leaf area, and dry matter of plants. Bedbabis et al. [32] reported an increase in P content as a result of the fertilization impact of TWW applied for irrigation. Application rates of TWW increased the nutrient inputs, higher uptake, and accumulation of nutrients (macro- and micro-nutrients), which consequently increased the dry matter and leaf area index of maize [60]. In addition, TWW may contain different types of bacteria that degrade or decompose organic matter in the soil, maintain soil fertility, and improve the water-holding capacity of the soil, porosity, and other physicochemical characteristics of the soil. Thus, TWW can be utilized to improve crop production and soil physical properties $[65,66]$. Sorghum and sunflower growth and productivity are improved by irrigating with TWW $[67,68]$. According to Aman et al. [66], the highest shoot fresh weight is observed in Cercis siliquastrum, Caesalpinia gilliesii, and Robinia pseudoacacia seedlings when irrigated with TWW. Similarly, several other studies showed positive effects of TWW on the growth of different plants $[41,54,62,69-75]$ because of optimal nutrient availability and uptake [76].

The total chlorophyll content of plants is a vital parameter because it shows the physiological status and photosynthetic activity of plants. Results indicated that maize, sorghum, and pearl millet plants exhibited higher total chlorophyll content when irrigated with TWW than with GW. The increase in chlorophyll content of crops may be linked to improvement in the mineral status of plants (Table 8 and Figure 2) and/or the increase of leaf area of plants (Tables 4 and 5) that increased the light interception and optimized the $\mathrm{CO}_{2}$ assimilation and therefore the photosynthetic capacity of plants. In the current study, a high amount of the total N (total N 188.0-211.5 $\mathrm{kg} \mathrm{ha}^{-1}$ ) was added through TWW. Usually, $\mathrm{N}$ is not often immobilized when rich organic material with $\mathrm{N}$ is applied into agricultural soil, this could be due to the total enough $\mathrm{N}$ for demanding of microorganism. This means that the inorganic $\mathrm{N}$ will increase as a result of organic matter mineralization [33,39,41]. The nutrients status in crops can be improved also by the mycorrhizal root colonization as was reported by Seleiman et al. [39], since the mycorrhizal fungi can enhance the uptake of mineralized $\mathrm{N}$ for their host crops. In this context, Faizan et al. [71] reported higher chlorophyll a, chlorophyll b, and total chlorophyll content in okra (Abelmoschus esculentus $\mathrm{L}$. Moench) irrigated with TWW compared with GW. In addition, young olive plants irrigated with TWW showed an improvement in growth, soluble sugars and photosynthesis rate, and chlorophyll a, b, and total chlorophyll contents [77]. Similarly, Helaly et al. [78] found that TWW irrigation positively affects the total chlorophyll content of Mango (Mangifera indica L.) trees. Maize plants irrigated with TWW along with municipal wastewater showed an improvement in chlorophyll content and growth [79].

The profitability of bioenergy crops grown for energy is determined by their dry matter yield and energy output [33]. Dry matter yield depends on the genetic potential of plants, climate and soil conditions, and agricultural practices $[80,81]$. The current study showed that the maize, sorghum, and pearl millet irrigated with TWW using 50\% recommended dose of NPK showed higher energy content (heating value), gross energy value, and lower ash content than the crops irrigated with GW along with the same amount of NPK fertilizer 
(Tables 6 and 7). The increase in gross energy value of the crops irrigated with TWW was due to the increase in the biomass of crops (Tables 4-7), considering that the biomass yield is the main factor determining the gross energy yield [33]. TWW did not cause toxic or heavy metal stress to plants and provided a sufficient amount of nutrients to plants, which increased the biomass and gross energy. Seleiman et al. [33] reported that sewage sludge, the solid by-product of TWW in wastewater treatment plants, slightly enhances the gross energy yield of hemp and maize compared with other treatments.

The plants (maize, sorghum, and pearl millet) irrigated with TWW showed higher nutrient elements and heavy metals, such as $\mathrm{N}, \mathrm{P}, \mathrm{K}, \mathrm{Cu}, \mathrm{Zn}, \mathrm{Fe}, \mathrm{Pb}, \mathrm{Ni}, \mathrm{Co}$, and $\mathrm{Cd}$, compared with the plants irrigated with GW (Table 8 and Figure 2). However, the concentrations of heavy metals in the plant biomass obtained from the current study were below the permissible limits. The increase in nutrient elements observed in maize, sorghum, and pearl millet plants irrigated with TWW could be due to the sufficient quantities of these elements in TWW and plant root zones that are bioavailable to plants, which consequently lead to their high concentrations in plant biomass. Tzortzakis et al. [62] revealed that irrigating plants with TWW can enhance the availability of $\mathrm{N}$ and $\mathrm{P}$ in the root zone; consequently, plants can uptake high $\mathrm{N}$ and P contents. Furthermore, Faizan et al. [71] reported an increase for $\mathrm{N}, \mathrm{P}$, and $\mathrm{K}$ in okra leaves when plants are irrigated with TWW rather than GW. Thus, the use of TWW for irrigation can enhance the nutrient contents of soil by acting as a fertilizer. It can also enhance the mineralization rate and facilitate nutrient uptake [82]. Bedbabis et al. [32] found an increase in P content in plant dry biomass irrigated with TWW. Similarly, El-Nahhal et al. [60] reported that irrigation with TWW enhances nutrient inputs, high uptake, and accumulation of nutrient elements, resulting in a high dry matter of maize. The use of TWW as a source of irrigation for crops can improve the phosphorus content in the soil and plants and enhance plant growth by preventing phosphorus deficiency in plants [76]. An increase in heavy metal contents but within permissible limits in plant seeds was observed when plants were irrigated with TWW [71]. Several other studies have reported an increase in soil nutrient status when irrigated with TWW for crop production $[83,84]$. Therefore, the application of TWW for crop irrigation can supply additional nutrient elements to the soil and can increase their absorption to the plants. Thus, TWW can reduce the quantity of mineral fertilizers applied as found in our investigation.

In the current study, the high performance of the potential bioenergy crops fertilized with a $50 \%$ recommended dose of NPK indicates that a $100 \%$ recommended dose of NPK applied with TWW might cause salt stress. As a result, the 100\% NPK dose did not cause a significant superiority on some growth, productivity, and energy traits in the current study compared with the application of 50\% NPK of the recommended dose. Mojid et al. [84] reported that the high application of fertilizers can cause a restriction of yield increase in the wastewater-irrigated crops. Conversely, Abou El Hassan et al. [85], Aziz [70] and El-Aziz [86] reported that a lower dose of NPK fertilizer performed better than a higher dose of NPK under traditional irrigation water. Similarly, Duarah et al. [87] observed that $50 \%$ NPK along with solubilizing bacteria showed better growth of plants compared with $100 \%$ NPK. In addition, wastewater can be used as an alternative source for crop irrigation in arid and semi-arid environments [32,88]. Thus, $100 \%$ NPK dose along with TWW could be in an excess amount of nutrients and may not be a beneficial application for the growth and productivity of crops used for bioenergy production. Excess dose of fertilizer can alter the soil properties by developing high salt concentration, and this phenomenon can upset beneficial microorganisms in the soil. TWW can increase the fertilizer use efficiency of NPK by increasing the uptake of nutrients added through fertilizer application. Thus, fertilizer rates could be reduced with the use of TWW because TWW can serve not only as the source of water but also of nutrients, particularly N, P, and K, and other micronutrients, such as $\mathrm{Zn}$ and B. Moreover, it could help reduce the environmental pollution caused by the over-application of fertilizers. 


\section{Conclusions}

TWW can be used as irrigation to enhance the growth and biomass productivity of crops used for bioenergy production in arid regions. In addition, maize, sorghum, and pearl millet irrigated with TWW in old or virgin soil accumulated higher concentration of macro (NPK) and trace (Fe, Mn, $\mathrm{Cu}, \mathrm{Zn}, \mathrm{Cd}, \mathrm{Pb}, \mathrm{Ni}$, and $\mathrm{Co}$ ) elements without negative impacts on crop productivity in terms of biomass accumulation and gross energy. Moreover, the application of a 50\% recommended dose of NPK fertilizer with TWW improved plant growth and all other measured parameters of plants with few exceptions. Thus, TWW could reduce the full recommended dose of NPK fertilizer up to $50 \%$ without inducing negative effects on the growth and energy production of potential bioenergy crops. Thus, TWW not only serves as an important source of plant nutrients but also protects the environment and decreases the leaching of excessive fertilizer application into groundwater. Therefore, irrigation with TWW in agriculture would be an important strategy for crops allocated for bioenergy production in Saudi Arabia because it does not harm plants and the environment.

Author Contributions: Conceptualization, N.A.-S., M.F.S., S.E.-H. and A.A.; methodology, N.A.-S., M.F.S., K.A. and S.E.-H.; software, M.F.S., S.E.-H., N.A.-S. and M.A.; formal analysis, M.F.S., S.E.-H. and N.A.-S.; investigation, N.A.-S., M.F.S. and S.E.-H.; resources, N.A.-S., M.F.S. and S.E.-H.; data curation, N.A.-S., M.F.S., S.E.-H., K.A., M.A. and A.A. writing-original draft preparation, M.F.S.; writing-review and editing, N.A.-S., M.F.S. and S.E.-H.; project administration, N.A.-S., A.A., M.F.S., S.E.-H. and M.A. All authors have read and agreed to the published version of the manuscript.

Funding: The authors extend their appreciation to the National Plan for Science, Technology, and innovation (MAARIFAH) at the King Abdul-Aziz City for Science and Technology, Saudi Arabia for funding this work through Award Project No. (12-WAT3141-02).

Institutional Review Board Statement: Not applicable.

Informed Consent Statement: Not applicable.

Data Availability Statement: All data are presented within the article.

Acknowledgments: The authors extend their appreciation to the National Plan for Science, Technology, and innovation (MAARIFAH) at the King Abdul-Aziz City for Science and Technology, Saudi Arabia for funding this work through Award Project No. (12-WAT3141-02) and and the Researchers Support \& Services Unit (RSSU) for their technical support.

Conflicts of Interest: The authors declare no conflict of interest.

\section{References}

1. Ozturk, M.; Saba, N.; Altay, V.; Iqbal, R.; Hakeem, K.R.; Jawaid, M.; Ibrahim, F.H. Biomass and Bioenergy: An Overview of the Development Potential in Turkey and Malaysia. Renew. Sustain. Energy Rev. 2017, 79, 1285-1302. [CrossRef]

2. Wu, Y.; Zhao, F.; Liu, S.; Wang, L.; Qiu, L.; Alexandrov, G.; Jothiprakash, V. Bioenergy Production and Environmental Impacts. Geosci. Lett. 2018, 5, 14. [CrossRef]

3. Yadav, P.; Priyanka, P.; Kumar, D.; Yadav, A.; Yadav, K. Bioenergy Crops: Recent Advances and Future Outlook. Prospect. Renew. Bioprocess. Futur. Energy Syst. 2019, 315-335. [CrossRef]

4. Seleiman, M.F. Towards Sustainable Intensification of Feedstock Production with Nutrient Cycling. Ph.D. Thesis, University of Helsinki, Helsinki, Finland, 2014. Available online: https:/ /helda.helsinki.fi/handle/10138/42898?show=full (accessed on 1 May 2021).

5. Schröder, P.; Beckers, B.; Daniels, S.; Gnädinger, F.; Maestri, E.; Marmiroli, N.; Mench, M.; Millan, R.; Obermeier, M.M.; Oustrière, N. Intensify Production, Transform Biomass to Energy and Novel Goods and Protect Soils in Europe-a Vision How to Mobilize Marginal Lands. Sci. Total Environ. 2018, 616, 1101-1123. [CrossRef] [PubMed]

6. Skoufogianni, E.; Solomou, A.; Charvalas, G.; Danalatos, N. Maize as Energy Crop. In Maize-Production and Use; IntechOpen: London, UK, 2019.

7. Von Cossel, M.; Wagner, M.; Lask, J.; Magenau, E.; Bauerle, A.; Von Cossel, V.; Warrach-Sagi, K.; Elbersen, B.; Staritsky, I.; Van Eupen, M. Prospects of Bioenergy Cropping Systems for a More Social-Ecologically Sound Bioeconomy. Agronomy 2019, 9, 605. [CrossRef]

8. Voloshin, R.A.; Rodionova, M.V.; Zharmukhamedov, S.K.; Nejat Veziroglu, T.N.; Allakhverdiev, S.I. Review: Biofuel Production from Plant and Algal Biomass. Int. J. Hydrogen Energy 2016, 41, 17257-17273. [CrossRef]

9. Mathur, S.; Umakanth, A.V.; Tonapi, V.A.; Sharma, R.; Sharma, M.K. Sweet Sorghum as Biofuel Feedstock: Recent Advances and Available Resources. Biotechnol. Biofuels 2017, 10, 146. [CrossRef] [PubMed] 
10. Crookston, B.; Blaser, B.; Darapuneni, M.; Rhoades, M. Pearl Millet Forage Water Use Efficiency. Agronomy $2020,10,1672$. [CrossRef]

11. Dinh, T.H.; Watanabe, K.; Takaragawa, H.; Nakabaru, M.; Kawamitsu, Y. Photosynthetic Response and Nitrogen Use Efficiency of Sugarcane under Drought Stress Conditions with Different Nitrogen Application Levels. Plant Prod. Sci. 2017, 20 , 412-422. [CrossRef]

12. Anders, A.; Markowski, P.; Konopka, S.; Kaliniewicz, Z.; Lipinski, A.J.; Choszcz, D.J. Effect of Seeding Rate on Selected Physical Parameters and Biomass Yield of Maize. Chil. J. Agric. Res. 2020, 80, 171-180. [CrossRef]

13. Belay, M.; Adare, K. Response of Growth, Yield Components, and Yield of Hybrid Maize (Zea Mays L.) Varieties to Newly Introduced Blended NPS and N Fertilizer Rates at Haramaya, Eastern Ethiopia. Cogent Food Agric. 2020, 6, 1771115. [CrossRef]

14. Seleiman, M.F.; Selim, S.; Jaakkola, S.; Mäkelä, P.S. Chemical composition and in vitro digestibility of whole-crop maize fertilized with synthetic fertilizer or digestate and harvested at two maturity stages in boreal growing conditions. Agric. Food Sci. 2017, 26, 47-55. [CrossRef]

15. Shahandeh, H.; Hons, F.M.; Wight, J.P.; Storlien, J.O. Harvest Strategy and N Fertilizer Effects on Bioenergy Sorghum Production. Aims Energy 2015, 3, 377-400. [CrossRef]

16. Lana, M.A.; Vasconcelos, A.C.F.; Gornott, C.; Schaffert, A.; Bonatti, M.; Volk, J.; Graef, F.; Kersebaum, K.C.; Sieber, S. Is Dry Soil Planting an Adaptation Strategy for Maize Cultivation in Semi-Arid Tanzania? Food Secur. 2018, 10, 897-910. [CrossRef]

17. Naoura, G.; Emendack, Y.; Baloua, N.; Vom Brocke, K.; Hassan, M.A.; Sawadogo, N.; Nodjasse, A.D.; Djinodji, R.; Trouche, G.; Laza, H.E. Characterization of Semi-Arid Chadian Sweet Sorghum Accessions as Potential Sources for Sugar and Ethanol Production. Sci. Rep. 2020, 10, 14947. [CrossRef]

18. Druille, M.; Williams, A.S.; Torrecillas, M.; Kim, S.; Meki, N.; Kiniry, J.R. Modeling Climate Warming Impacts on Grain and Forage Sorghum Yields in Argentina. Agronomy 2020, 10, 964. [CrossRef]

19. Almodares, A.; Taheri, R.; Adeli, S. Stalk Yield and Carbohydrate Composition of Sweet Sorghum [Sorghum Bicolor (L.) Moench] Cultivars and Lines at Different Growth Stages. J. Males. Appl. Biol. 2008, 37, 31-36.

20. Dou, F.; Wight, J.P.; Wilson, L.T.; Storlien, J.O.; Hons, F.M. Simulation of Biomass Yield and Soil Organic Carbon under Bioenergy Sorghum Production. PLoS ONE 2014, 9, e115598. [CrossRef]

21. López-Sandin, I.; Gutiérrez-Soto, G.; Gutiérrez-Díez, A.; Medina-Herrera, N.; Gutiérrez-Castorena, E.; Zavala-García, F. Evaluation of the Use of Energy in the Production of Sweet Sorghum (Sorghum Bicolor (L.) Moench) under Different Production Systems. Energies 2019, 12, 1713. [CrossRef]

22. Jahansouz, M.R.; Afshar, R.K.; Heidari, H.; Hashemi, M. Evaluation of Yield and Quality of Sorghum and Millet as Alternative Forage Crops to Corn under Normal and Deficit Irrigation Regimes. Jordan J. Agric. Sci. 2014, 10, 699-715.

23. Xu, Y.; Porter, N.; Foster, J.L.; Muir, J.P.; Schwab, P.; Burson, B.L.; Jessup, R.W. Silica Production across Candidate Lignocellulosic Biorefinery Feedstocks. Agronomy 2020, 10, 82. [CrossRef]

24. Tadele, Z. Drought Adaptation in Millets; InTech: London, UK, 2016.

25. Ausiku, A.P.; Annandale, J.G.; Steyn, J.M.; Sanewe, A.J. Improving Pearl Millet (Pennisetum Glaucum) Productivity through Adaptive Management of Water and Nitrogen. Water 2020, 12, 422. [CrossRef]

26. Ullah, A.; Ahmad, A.; Khaliq, T.; Akhtar, J. Recognizing Production Options for Pearl Millet in Pakistan under Changing Climate Scenarios. J. Integr. Agric. 2017, 16, 762-773. [CrossRef]

27. Rai, K.N.; Govindaraj, M.; Rao, A.S. Genetic Enhancement of Grain Iron and Zinc Content in Pearl Millet. Qual. Assur. Saf. Crop. Foods 2012, 4, 119-125. [CrossRef]

28. Nasr, F.A.; El-Shafai, S.A.; Abdelfadil, A.S.; Ibrahim, H.S.; Hemdan, B.A. Potential Use of Treated Domestic Sewage for Cultivation of Biofuel Crops in Egypt. Int. J. Environ. Sci. Technol. 2019, 16, 7433-7442. [CrossRef]

29. Agoro, M.A.; Adeniji, A.O.; Adefisoye, M.A.; Okoh, O.O. Heavy Metals in Wastewater and Sewage Sludge from Selected Municipal Treatment Plants in Eastern Cape Province, South Africa. Water 2020, 12, 2746. [CrossRef]

30. Balkhair, K.S.; Ashraf, M.A. Field Accumulation Risks of Heavy Metals in Soil and Vegetable Crop Irrigated with Sewage Water in Western Region of Saudi Arabia. Saudi J. Biol. Sci. 2016, 23, S32-S44. [CrossRef]

31. Singh, A.; Sharma, R.K.; Agrawal, M.; Marshall, F.M. Health Risk Assessment of Heavy Metals via Dietary Intake of Foodstuffs from the Wastewater Irrigated Site of a Dry Tropical Area of India. Food Chem. Toxicol. 2010, 48, 611-619. [CrossRef]

32. Seleiman, M.F.; Kheir, A.M.S.; Al-Dhumri, S.; Alghamdi, A.G.; Omar, E.-S.H.; Aboelsoud, H.M.; Abdella, K.A.; Abou El Hassan, W.H. Exploring Optimal Tillage Improved Soil Characteristics and Productivity of Wheat Irrigated with Different Water Qualities. Agronomy 2019, 9, 233. [CrossRef]

33. Seleiman, M.F.; Santanen, A.; Jaakkola, S.; Ekholm, P.; Hartikainen, H.; Stoddard, F.L.; Mäkelä, P.S.A. Biomass Yield and Quality of Bioenergy Crops Grown with Synthetic and Organic Fertilizers. Biomass Bioenergy 2013, 59, 477-485. [CrossRef]

34. Zhang, Y.; Shen, Y. Wastewater Irrigation: Past, Present, and Future. Wiley Interdiscip. Rev. Water 2019, 6, e1234. [CrossRef]

35. Samarah, N.H.; Bashabsheh, K.Y.; Mazahrih, N.T. Treated Wastewater Outperformed Freshwater for Barley Irrigation in Arid Lands. Ital. J. Agron. 2020, 15, 183-193. [CrossRef]

36. Jahany, M.; Rezapour, S. Assessment of the Quality Indices of Soils Irrigated with Treated Wastewater in a Calcareous Semi-Arid Environment. Ecol. Indic. 2020, 109, 105800. [CrossRef]

37. Pandey, R.; Saxena, C. Drip Irrigation with Marginal Quality Land and Waters. In Sustainable Irrigated Agriculture; Command Area Development \& Water Management, Ministry of Water Resources: New Delhi, India, 2020; pp. 108-132. 
38. Maucieri, C.; Cavallaro, V.; Caruso, C.; Borin, M.; Milani, M.; Barbera, A.C. Sorghum Biomass Production for Energy Purpose Using Treated Urban Wastewater and Different Fertilization in a Mediterranean Environment. Agriculture 2016, 6, 67. [CrossRef]

39. Seleiman, M.F.; Santanen, A.; Kleemola, J.; Stoddard, F.L.; Mäkelä, P.S.A. Improved Sustainability of Feedstock Production with Sludge and Interacting Mycorrhiza. Chemosphere 2013, 91, 1236-1242. [CrossRef] [PubMed]

40. Al-Hadidi, L.M.; Dukah, M.; Shatanawi, M. Treatment and Reuse of Wastewater Using Surface and Subsurface Wetlands. Ph.D. Thesis, University of Jordan, Amman, Jordan, 2009.

41. Seleiman, M.F.; Santanen, A.; Mäkelä, P.S.A. Recycling Sludge on Cropland as Fertilizer-Advantages and Risks. Resour. Conserv. Recycl. 2020, 155, 104647. [CrossRef]

42. Wang, H.; Zhou, J.; Du, C.; Chen, X. Potassium Fractions in Soils as Affected by Monocalcium Phosphate, Ammonium Sulfate, and Potassium Chloride Application. Pedosphere 2010, 20, 368-377. [CrossRef]

43. Chandini, K.R.; Kumar, R.; Prakash, O. The Impact of Chemical Fertilizers on Our Environment and Ecosystem. In Research Trends in Environment Science; AkiNik Publications: Delhi, India, 2019; pp. 69-86.

44. Seleiman, M.F.; Almutairi, K.F.; Alotaibi, M.; Shami, A.; Alhammad, B.A.; Battaglia, M.L. Nano-Fertilization as an Emerging Fertilization Technique: Why Can Modern Agriculture Benefit from Its Use? Plants 2021, 10, 2. [CrossRef]

45. Ayilara, M.S.; Olanrewaju, O.S.; Babalola, O.O.; Odeyemi, O. Waste Management through Composting: Challenges and Potentials. Sustainability 2020, 12, 4456. [CrossRef]

46. Bai, Y.C.; Chang, Y.Y.; Hussain, M.; Lu, B.; Zhang, J.P.; Song, X.B.; Lei, X.S.; Pei, D. Soil Chemical and Microbiological Properties Are Changed by Long-Term Chemical Fertilizers That Limit Ecosystem Functioning. Microorganisms 2020, 8, 694. [CrossRef]

47. Bahram, M.; Hildebrand, F.; Forslund, S.K.; Anderson, J.L.; Soudzilovskaia, N.A.; Bodegom, P.M.; Bengtsson-Palme, J.; Anslan, S.; Coelho, L.P.; Harend, H. Structure and Function of the Global Topsoil Microbiome. Nature 2018, 560, 233-237. [CrossRef] [PubMed]

48. Zheng, F.; Zhu, D.; Giles, M.; Daniell, T.; Neilson, R.; Zhu, Y.-G.; Yang, X.-R. Mineral and Organic Fertilization Alters the Microbiome of a Soil Nematode Dorylaimus Stagnalis and Its Resistome. Sci. Total Environ. 2019, 680, 70-78. [CrossRef] [PubMed]

49. Hartley, T.N.; Macdonald, A.J.; McGrath, S.P.; Zhao, F.-J. Historical Arsenic Contamination of Soil Due to Long-Term Phosphate Fertiliser Applications. Environ. Pollut. 2013, 180, 259-264. [CrossRef] [PubMed]

50. Demirsoy, L.; Demirsoy, H.; Balci, G. Different Growing Conditions Affect Nutrient Content, Fruit Yield and Growth in Strawberry. Pak. J. Bot. 2012, 44, 125-129.

51. Tong, Z.; Quan, G.; Wan, L.; He, F.; Li, X. The Effect of Fertilizers on Biomass and Biodiversity on a Semi-Arid Grassland of Northern China. Sustainability 2019, 11, 2854. [CrossRef]

52. Cottenie, A.; Verloo, M.; Velghe, M.; Camerlynck, R. Chemical Analysis of Plant and Soil. Manual Laboratory of Analytical and Agrochemistry; Ghent State Univ. Press: Ghent, Belgium, 1982.

53. Burt, R. Soil Survey Laboratory Manual Report No. 42 USDA, National Resources Conservation Service; 1100; United States Department of Agriculture: Washington, DC, USA, 2004.

54. Seleiman, M.F.; Santanen, A.; Stoddard, F.L.; Mäkelä, P. Feedstock Quality and Growth of Bioenergy Crops Fertilized with Sewage Sludge. Chemosphere 2012, 89, 1211-1217. [CrossRef] [PubMed]

55. Urbano, V.R.; Mendonça, T.G.; Bastos, R.G.; Souza, C.F. Effects of Treated Wastewater Irrigation on Soil Properties and Lettuce Yield. Agric. Water Manag. 2017, 181, 108-115. [CrossRef]

56. Anwar, S.; Nawaz, M.F.; Gul, S.; Rizwan, M.; Ali, S.; Kareem, A. Uptake and Distribution of Minerals and Heavy Metals in Commonly Grown Leafy Vegetable Species Irrigated with Sewage Water. Environ. Monit. Assess. 2016, 188, 541. [CrossRef]

57. Acosta-Motos, J.R.; Diaz-Vivancos, P.; Álvarez, S.; Fernández-García, N.; Sanchez-Blanco, M.J.; Hernández, J.A. Physiological and Biochemical Mechanisms of the Ornamental Eugenia Myrtifolia L. Plants for Coping with NaCl Stress and Recovery. Planta 2015, 242, 829-846. [CrossRef]

58. Cantabella, D.; Piqueras, A.; Acosta-Motos, J.R.; Bernal-Vicente, A.; Hernández, J.A.; Díaz-Vivancos, P. Salt-Tolerance Mechanisms Induced in Stevia Rebaudiana Bertoni: Effects on Mineral Nutrition, Antioxidative Metabolism and Steviol Glycoside Content. Plant Physiol. Biochem. 2017, 115, 484-496. [CrossRef]

59. Mousavi, S.R.; Galavi, M.; Eskandari, H. Effects of Treated Municipal Wastewater on Fluctuation Trend of Leaf Area Index and Quality of Maize (Zea Mays). Water Sci. Technol. 2013, 67, 797-802. [CrossRef]

60. El-Nahhal, Y.; Tubail, K.; Safi, M.; Safi, J.M. Effect of Treated Waste Water Irrigation on Plant Growth and Soil Properties in Gaza Strip, Palestine. Am. J. Plant Sci. 2013, 4, 1736-1743. [CrossRef]

61. Zema, D.A.; Bombino, G.; Andiloro, S.; Zimbone, S.M. Irrigation of Energy Crops with Urban Wastewater: Effects on Biomass Yields, Soils and Heating Values. Agric. Water Manag. 2012, 115, 55-65. [CrossRef]

62. Tzortzakis, N.; Saridakis, C.; Chrysargyris, A. Treated Wastewater and Fertigation Applied for Greenhouse Tomato Cultivation Grown in Municipal Solid Waste Compost and Soil Mixtures. Sustainability 2020, 12, 4287. [CrossRef]

63. Dagianta, E.; Goumas, D.; Manios, T.; Tzortzakis, N. The Use of Treated Wastewater and Fertigation in Greenhouse Pepper Crop as Affecting Growth and Fruit Quality. J. Water Reuse Desalination 2014, 4, 92-99. [CrossRef]

64. Morgan, J.Á.B.; Connolly, E.L. Plant-Soil Interactions: Nutrient Uptake. Nat. Educ. Knowl. 2013, 4, 2.

65. Khan, M.A.; Shaukat, S.S.; Khan, M.A. Economic Benefits from Irrigation of Maize with Treated Effluent of Waste Stabilization Ponds. Pak. J. Bot. 2008, 40, 1091-1098. 
66. Aman, M.S.; Jafari, M.; Reihan, M.K.; Motesharezadeh, B.; Zare, S. Assessing the Effect of Industrial Wastewater on Soil Properties and Physiological and Nutritional Responses of Robinia Pseudoacacia, Cercis Siliquastrum and Caesalpinia Gilliesii Seedlings. J. Environ. Manag. 2018, 217, 718-726. [CrossRef]

67. Galavi, M.; Jalali, A.; Mousavi, S.R.; Galavi, H. Effect of Treated Municipal Wastewater on Forage Yield, Quantitative and Qualitative Properties of Sorghum (S. bicolor Speed Feed). Asian J. Plant Sci. 2009, 8, 489-494. [CrossRef]

68. Khan, M.A.; Shaukat, S.S.; Khan, M.A. Growth, Yield and Nutrient Content of Sunflower (Helianthus Annuus L.) Using Treated Wastewater from Waste Stabilization Ponds. Pak. J. Bot. 2009, 41, 1391-1399.

69. Akhtar, N.; Inam, A.; Inam, A.; Khan, N.A. Effects of City Wastewater on the Characteristics of Wheat with Varying Doses of Nitrogen, Phosphorus, and Potassium. Recent Res. Sci. Technol. 2012, 4, 18-29.

70. Aziz, F.; Farissi, M. Reuse of Treated Wastewater in Agriculture: Solving Water Deficit Problems in Arid Areas. Ann. West Univ. Timis. Ser. Biol. 2014, 17, 95.

71. Faizan, S.; Kausar, S.; Akhtar, N. Influence of Wastewater Application and Fertilizer Use on Growth, Photosynthesis, Nutrient Homeostatis, Yield and Heavy Metal Accumulation in Okra (Abelmoschus Esculentus L. Moench). Pak. J. Biol. Sci. 2014, 17, 630-640. [CrossRef] [PubMed]

72. Gatta, G.; Libutti, A.; Beneduce, L.; Gagliardi, A.; Disciglio, G.; Lonigro, A.; Tarantino, E. Reuse of Treated Municipal Wastewater for Globe Artichoke Irrigation: Assessment of Effects on Morpho-Quantitative Parameters and Microbial Safety of Yield. Sci. Hortic. 2016, 213, 55-65. [CrossRef]

73. Tekaya, M.; Mechri, B.; Dabbaghi, O.; Mahjoub, Z.; Laamari, S.; Chihaoui, B.; Boujnah, D.; Hammami, M.; Chehab, H. Changes in Key Photosynthetic Parameters of Olive Trees Following Soil Tillage and Wastewater Irrigation, Modified Olive Oil Quality. Agric. Water Manag. 2016, 178, 180-188. [CrossRef]

74. Vergine, P.; Salerno, C.; Libutti, A.; Beneduce, L.; Gatta, G.; Berardi, G.; Pollice, A. Closing the Water Cycle in the Agro-Industrial Sector by Reusing Treated Wastewater for Irrigation. J. Clean. Prod. 2017, 164, 587-596. [CrossRef]

75. Reis, M.M.; da Silva, A.J.; Santos, L.D.T.; Lopes, É.M.G.; Barros, R.E.; Donato, L.M.S. Millet Irrigation with Treated Wastewater: Gas Exchange Response and Nutrient Accumulation. Ciência Agrotecnol. 2019, 43, e023519. [CrossRef]

76. Ofori, S.; Puškáčová, A.; Růžičková, I.; Wanner, J. Treated Wastewater Reuse for Irrigation: Pros and Cons. Sci. Total Environ. 2020, 760, 144026. [CrossRef]

77. Hassena, A.B.; Zouari, M.; Trabelsi, L.; Khabou, W.; Zouari, N. Physiological Improvements of Young Olive Tree (Olea Europaea L. Cv. Chetoui) under Short Term Irrigation with Treated Wastewater. Agric. Water Manag. 2018, 207, 53-58. [CrossRef]

78. Helaly, M.N.; El-Sheery, N.I.; El-Hoseiny, H.; Rastogi, A.; Kalaji, H.M.; Zabochnicka-Świątek, M. Impact of Treated Wastewater and Salicylic Acid on Physiological Performance, Malformation and Yield of Two Mango Cultivars. Sci. Hortic. 2018, 233, 159-177. [CrossRef]

79. Younas, S.; Rizvi, H.; Ali, S.; Abbas, F. Irrigation of Zea Mays with UASB-Treated Textile Wastewater; Effect on Early Irrigation of Zea Mays with UASB-Treated Textile Wastewater; Effect on Early Growth and Physiology. Environ. Sci. Pollut. Res. Int. 2020, 27, 15305-15324. [CrossRef]

80. Jankowski, K.J.; Dubis, B.; Sokólski, M.M.; Załuski, D.; Bórawski, P.; Szempliński, W. Productivity and Energy Balance of Maize and Sorghum Grown for Biogas in a Large-Area Farm in Poland: An 11-Year Field Experiment. Ind. Crop. Prod. 2020, 148, 112326. [CrossRef]

81. Stolarski, M.J.; Śnieg, M.; Krzyżaniak, M.; Tworkowski, J.; Szczukowski, S. Short Rotation Coppices, Grasses and Other Herbaceous Crops: Productivity and Yield Energy Value versus 26 Genotypes. Biomass Bioenergy 2018, 119, 109-120. [CrossRef]

82. Quemada, M.; Delgado, A.; Mateos, L.; Villalobos, F.J. Nitrogen Fertilization I: The Nitrogen Balance. In Principles of Agronomy for Sustainable Agriculture; Springer: Berlin/Heidelberg, Germany, 2016; pp. 341-368.

83. Singh, P.K.; Deshbhratar, P.B.; Ramteke, D.S. Effects of Sewage Wastewater Irrigation on Soil Properties, Crop Yield and Environment. Agric. Water Manag. 2012, 103, 100-104. [CrossRef]

84. Mojid, M.A.; Wyseure, G.C.L.; Biswas, S.K. Requirement of Nitrogen, Phosphorus and Potassium Fertilizers for Wheat Cultivation under Irrigation by Municipal Wastewater. J. Soil Sci. Plant Nutr. 2012, 12, 655-665. [CrossRef]

85. Abou El Hassan, W.H.; Hafez, E.M.; Ghareib, A.; Ragab, M.F.; Seleiman, M.F. Impact of nitrogen fertilization and irrigation on N accumulation, growth and yields of Zea mays L. J. Food Agric. Environ. 2014, 12, 217-222.

86. Abd El-Aziz, N. Stimulatory Effect of NPK Fertilizer and Benzyladenine on Growth and Chemical Constituents of Codiaeum Variegatum L. Am. J. Agric. Environ. Sci. 2007, 2, 711-719.

87. Duarah, I.; Deka, M.; Saikia, N.; Boruah, H.P.D. Phosphate Solubilizers Enhance NPK Fertilizer Use Efficiency in Rice and Legume Cultivation. 3 Biotech 2011, 1, 227-238. [CrossRef]

88. Balkhair, K.S.; Ismail, S.M.; El-Nakhlawy, F.S.; Al-Solaimani, S.G. Impact of waste water irrigation on the yield and quality of white radish under arid environments. Life Sci. J. 2014, 11, 246-254. 